\title{
Titaniferous Magnetite Deposits Associated with Archean Greenstone Belt in the East Indian Sheild
}

\author{
Riya Mondal*, Tapan Kr. Baidya \\ Department of Geological Sciences, Jadavpur University, Kolkata: 700028, West Bengal, India
}

Email address:

riyamondal.dgr@gmail.com (R. Mondal)

\section{To cite this article:}

Riya Mondal, Tapan Kr. Baidya. Titaniferous Magnetite Deposits Associated with Archean Greenstone Belt in the East Indian Sheild. Earth Sciences. Special Issue: Archean Metallogeny and Crustal Evolution. Vol. 4, No. 4-1, 2015, pp. 15-30.

doi: $10.11648 /$ j.earth.s.2015040401.12

\begin{abstract}
In the East Indian Shield, occurrence of titaniferous magnetite deposits associated with the Archean Greenstone belt occur in Kumhardubi, Betjharan and Nuasahi areas of Odisha and Dublabera area of Jharkhand. The ore bodies comprise lenses, veins, bands and patches within gabbroic rocks. Petrogenetic studies have revealed the primary and secondary mineral constituents of the ores such as titanomagnetite, ilmenite, hematite, spinel, cobaltite, goethite, martite, rutile and silicate gangue minerals. Various crystallographic intergrowths are resulted from exsolution \& oxidation at different temperatures during cooling of the sub-solidus magma. Chemical analyses show that the ore contains $10.35-17.68$ wt.\% TiO2, $0.148-0.227$ wt.\% V2O3 and 32.75 - 67.39 wt.\% Fe2O3. Different geochemical composition diagrams confirm their tholeiitic origin. The formation of the massive ore bodies is referred to late magmatic crystallization from tholeiitic magma followed by Fe-Ti enriched residual liquid injection within the host rocks. Syn to late formation of the magnetite ores along with gabbroanorthositic intrusive with respect to the Archean Greenstone Belt of East Indian Shield is suggested.
\end{abstract}

Keywords: Magnetite, Archean, Orthomagmatic, Greenstone

\section{Introduction}

The titaniferous magnetite is an important ore for being used as principal source of $\mathrm{Ti}$ and $\mathrm{V}$ apart from $\mathrm{Fe}$. In the East Indian Shield (hereafter called as EIS), the titaniferous magnetite deposits are mainly located in Kumhardubi, Betjharan areas of Mayurbhanj district, Nuasahi of Kendujhar district of Odisha, Dublabera area of the West Singhbhum district, Jharkhand, Saltora - Mejia, Panrkidih Bheladih and Ramchandrapur - Tiludi areas of the Purulia and Bankura districts, West Bengal. Among these locations only the first four locations fall within the Archean terrain. Other occurrences of similar deposits in India are reported from Moulabhanj area of the Kendujhar district (Chakraborty and Mallick [1]) of Odisha, Shimoga (Vasudev and Srinivasan [2]; Vidyashankar and Govindaiah [3]) and Nuggihalli areas of Karnataka (Subba Rao, Basu, Balaram and Vidyasagar [4]). The ore bodies are commonly associated with gabbroic rocks. Such association is also reported from all over the world e.g. layered igneous complex of Bushveld, South Africa, massif type intrusives from the Adirondack \& Duluth complex, USA and several other locations. The area under investigation composed of unmetamorphosed gabbroic rocks which are intrusive into the Singhbhum granite and associated with Archean Iron Ore Group (hereafter called IOG). The present work includes local geology of the field area, detailed petrography, mineral chemistry and geochemistry of the ores, their petrogenetic and economic significance, paragenesis of the ore minerals, origin of V-Ti magnetite ores and stratigraphic correlation of these ore bodies along with their host rocks.

\section{Regional Geology}

The EIS comprises two major cratonic blocks viz. GraniteGreenstone region of Singhbhum and Granulite-Gneiss region of Chhotanagpur which are separated by the Singhbhum Orogenic Belt containing Dalma lavas and Singhbhum Group rocks. The studied area mainly falls within the Granite-Greenstone region of Singhbhum. The Granite-Greenstone region of Singhbhum is a low grade metamorphic terrain containing mafic-ultramafic rocks, sediments, volcanics and different types of granite mainly. The generalized precambrian chronostratigraphic succession in this craton is given below (after Saha [5]). 
Table 1: Chronostratigraphic succession of Singhbhum Granite-Greenstone terrane after Saha [5]

\begin{tabular}{ll}
\hline Newer Dolerite dykes \& sills & c. 1600-950 Ma \\
\hline Mayurbhanj Granite & c. $2100 \mathrm{Ma}$ \\
Gabbro-anorthosite-ultramafics (*Titaniferous magnetite-bearing ) & c. $2100-2200 \mathrm{Ma}$ \\
Kolhan Group & Dhanjori Group \\
Unconformity & Singhbhum Group \\
Jagannathpur Lava Dhanjori-Simlipal Lavas Malangtoli Lava Quartzite, Conglomerate (c. $2300 \mathrm{Ma})$ & \\
Pelitic and arenaceous metasediments with mafic sills (c. $2300-2400 \mathrm{Ma})$ & c. $3.1 \mathrm{Ga}$ \\
Unconformity & Iron Ore Group \\
Singhbhum Granite (SBG-B) Phase-III & Nilgiri Granite Bonai Granite \\
Mafic lava, tuff, acid volcanics, tuffaceous shale, banded hematite jasper and banded hematite quartzite with iron ores, \\
ferruginous chert, local dolomite and quartzitic sandstone & c. $3.4-3.5 \mathrm{Ga}$ \\
Singhbhum Granite (SBG-A) Phase-I \& II (c. 3.3 Ga) & $3.775 \mathrm{Ga}$ \\
Folding and metamorphism of OMG and OMTG & c. $4.0 \mathrm{Ga}$ \\
Older Metamorphic Tonalitic-gneiss (OMTG) & \\
Older Metamorphic Group (OMG): Pelitic schist, quartzite, para-amphibolite, ortho-amphibolite & \\
\hline
\end{tabular}

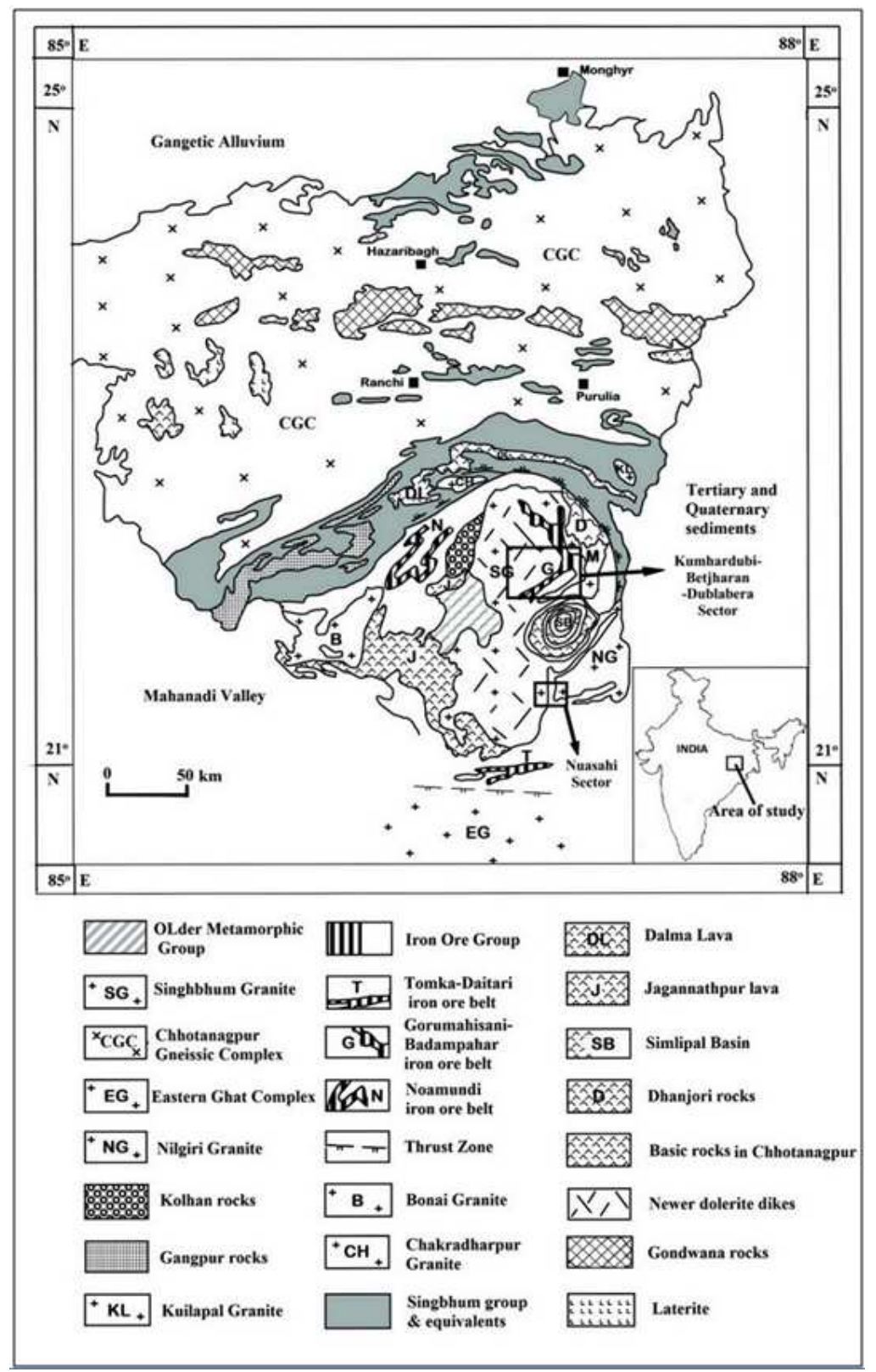

Fig. 1. Geological map of East Indian Shield showing location of titaniferous-vanadiferous magnetite sectors of Archean age. (after Baidya [14]). 
During Precambrian time the EIS suffered at least three orogenies. The earliest orogeny includes the rocks of OMG, OMTG and SBG-A. This earliest orogeny, also known as 'Older Metamorphic Orogeny', has a major time span of $>4.0$ $\mathrm{Ga}$ to $3.3 \mathrm{Ga}$. The OMG and OMTG were intruded by a major part of SBG-A around $3.3 \mathrm{Ga}$ and possibly the earliest greenstone rocks are included within OMG and OMTG. The second orogeny i.e., the 'Iron Ore Orogeny' formed the ideal greenstone belts with the development of three large iron ore basins viz. Noamundi-Jamda-Koira basin on the west, Gorumahisani-Badampahar basin on the east and TomkaDaitari basin on the south of the Singhbhum craton during the span mainly around $3.3 \mathrm{Ga}$. All these basins are characterized by the presence of volcanogenic sediments as well as iron formation, the principal components of the latter are banded hematite jasper (BHJ) and banded magnetite quartzite (BMQ). Almost simultaneously ultramafic and mafic magmatism also produced $\mathrm{Cr}$, Fe-Ti-V, Au-PGE mineralization in close association with the rocks of the IOG. The chromite deposits, PGE mineralization and titaniferous magnetite bodies hosted within ultramafics and gabbroanorthositic rocks of Baula-Nuasahi area are all formed during the Iron Ore Orogeny along with the IOG rocks and Fe-Mn ores. Fig. 1 shows the regional geological map of the EIS showing locations of titaniferous vanadiferous magnetite deposits of Archean age. The ore bodies along with their host gabbro-anorthosite in Nuasahi area has been dated with possible age limits of $3.3 \mathrm{Ga}$ and $3.1 \mathrm{Ga}$ by Auge [6].The titaniferous magnetite deposits in association of Gabbroanorthositic rocks in Kumhardubi-Betjharan and Dublabera areas of Mayurbhanj District and West Singhbhum district respectively, have been stratigraphically placed above Kolhan Group dated 2.1 - 2.2 Ga by Saha [5]. In contrast the basic rocks of Mayurbhanj district are claimed to be of Archean age as they are co-magmatic with the Archean mafic-ultramafic complex of Nuasahi area (Iyengar and Alwar [7]). Another occurrence of Archean titaniferous magnetite deposit hosted by gabbro-anorthositic suite, synchronous with Archean greenstone belt is reported from Nuggihalli Schist Belt $(>3.1 \mathrm{Ga})$ of Karnataka in South India (Subba Rao [4]). Such associations of Archean mafic intrusions with Archean greenstone belts have also been reported from elsewhere like Barberton greenstone belt (3.5 Ga), Kaapval Craton, South Africa (Shackleton [8]); Late Archean greenstone belt of Zimbabwe (the upper Bulawayan Supergroup, 2.85-2.66 Ga) (Wilson, Nesbitt and Fanning [9]); Greenstone belt of Pilbara Craton, Australia (3.5 to $2.9 \mathrm{Ga}$ ) (Trendall [10]); Hebei Province, China (Choukroune, Bouhallie and Arndt [11]); Yilgarn Craton, Western Australia (Myers [12]); Abitibi belt, Canada (Windley [13]). In this paper, the authors tried to establish the orthomagmatic magnetite mineralization associated with gabbro-anorthositic intrusives and chronostratigraphically correlating with the IOG.

\subsection{Local Geology of the Magnetite Zones}

Fig.2 shows the geological map of the magnetite mineralized zones of the Kumhardubi, Betjharan and Dublabera areas.

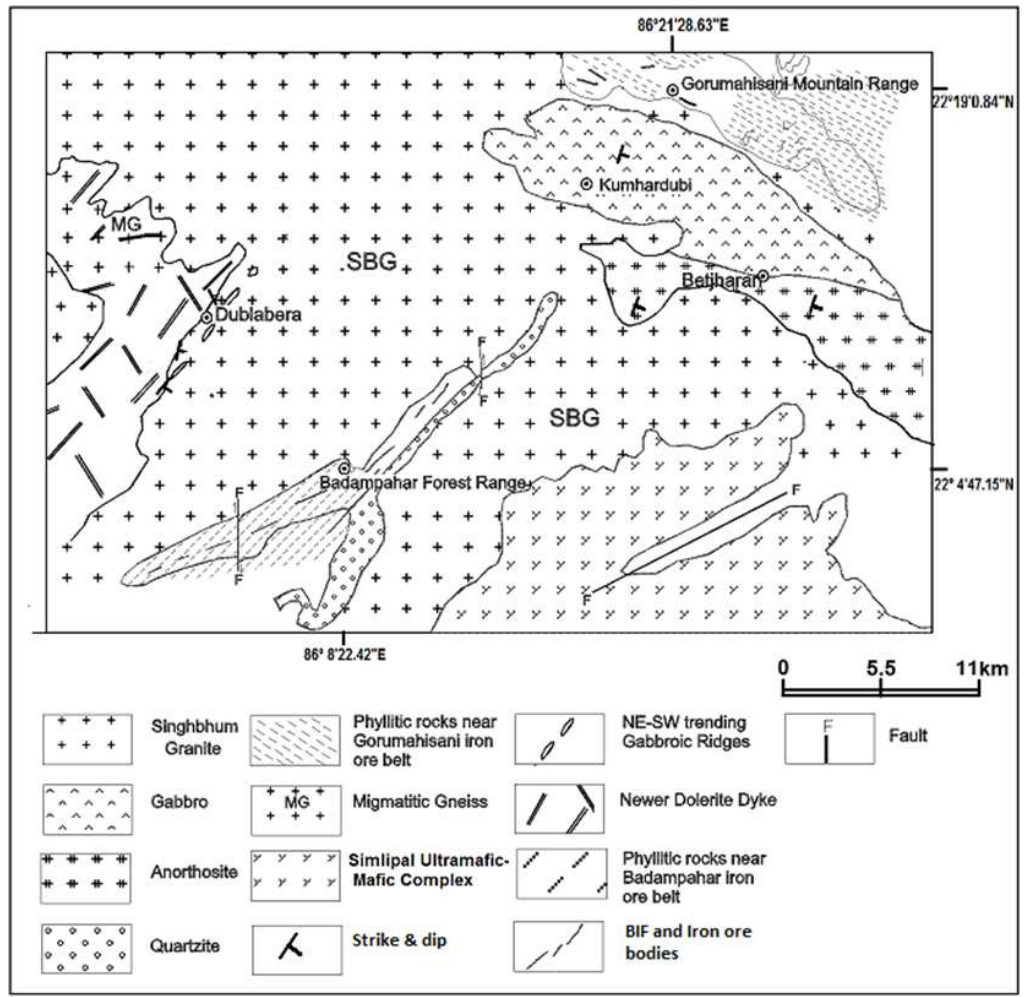

Fig. 2. Geological map of Titanifeous-Vanadiferous Magnetite sectors of Kumhardubi-Betjharan-Dublabera area. 


\subsubsection{Kumhardubi-Betjharan Area}

Here, the V-Ti-magnetite ore bodies hosted by gabbroic rocks occur as lensoid body within granitic rocks. Prominent epidotization and occurrence of granodioritic rock are present at the contact of the gabbroic intrusives and the granitic rocks. Within the lensoid intrusive body the Ti-V-magnetite ores occur in various forms i.e. lenses, veins, bands and patches. Detailed structural work shows that crude foliation present in gabbro having strike NNE-SSW and dip around 560 towards SE. Gneissic foliation in granite strikes NNW-SSE to NESW and dips 520 - 800 towards ENE or NW. Dolerite dyke is present in granitic rocks trend NNE-SSW. In Betjharan area, anorthosite is also present along with gabbro as host rock of Ti-V-magnetite ores. The anorthosite often contains enclaves of older metabasics (now transformed to amphibolite mainly). Crude foliation in the gabbro-anorthosite strikes 2150-2350 and dips $610-670$ towards SE.

\subsubsection{Dublabera Area}

The titaniferous magnetite bodies occur within the gabbroic rocks in close association with granite gneiss. The gabbroic rocks occur as small ridges (with trend varies from 750 to 450 ) cutting across the granite gneiss. The gabbroic rocks are mainly composed of feldspar, pyroxene with minor specks of magnetite and sulfide. Crude foliation in granite gneiss strikes 3350 to 3450 and dips around 740 to 760 towards NE.

\subsubsection{Nuasahi Area}

The titaniferous magnetite bodies occur in the form of subparallel bands (width from 1 meter to 20 meters) within gabbroic rock in the north-eastern part of the Nuasahi chromiferous ultramafic-mafic complex. The chromiferous ultramafic rocks are flanked by gabbroic rocks both on the eastern and western sides. The ultramafic-mafic complex is intruded within the Iron Ore Group of rocks. The general trend of the Ti-V-magnetite bands is NW-SE to WNW-ESE having dip around 740 towards NE.

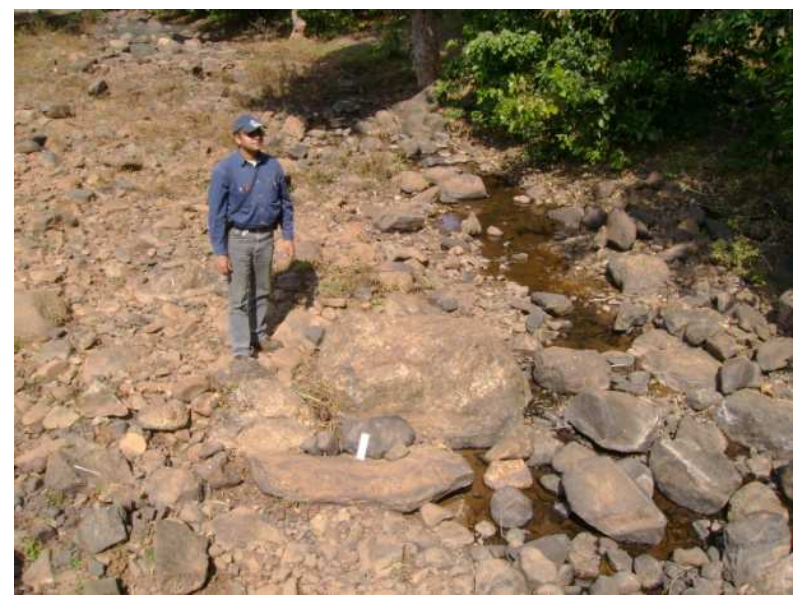

Fig. 3. Magnetite rich boulders in Kumhardubi.

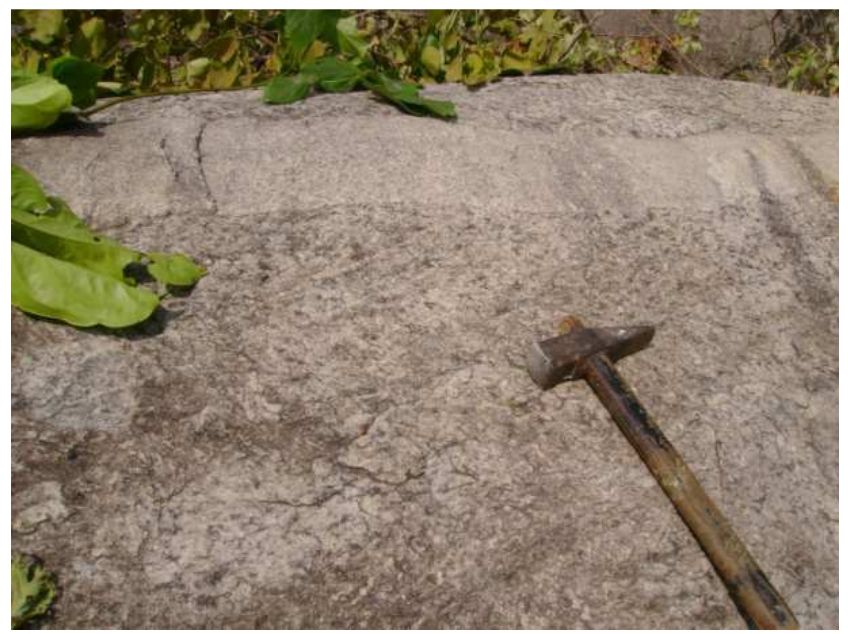

Fig. 4. Younger leucogranite vein transgressed the well foliated granitegneiss (Kumhardubi).

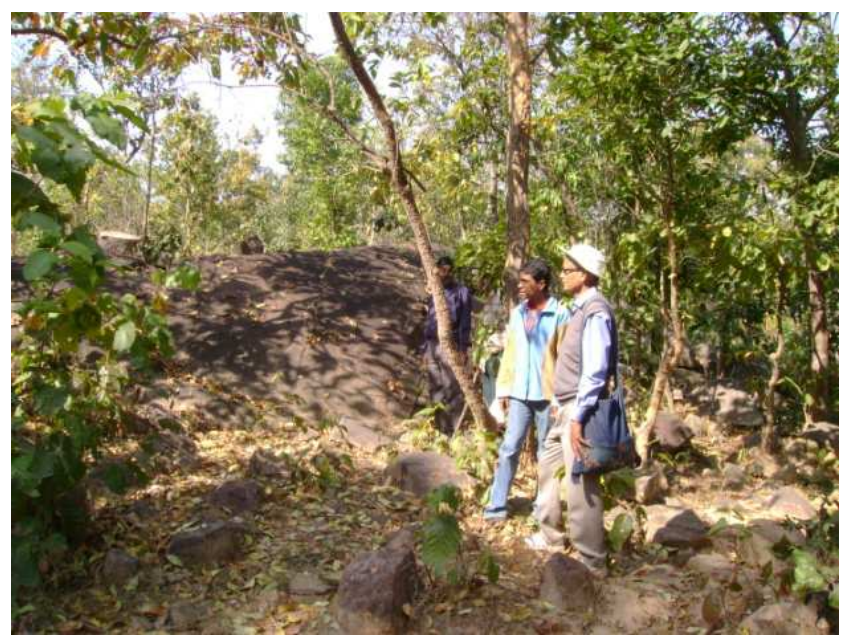

Fig. 5. Magnetite rich zone in Betjharan.

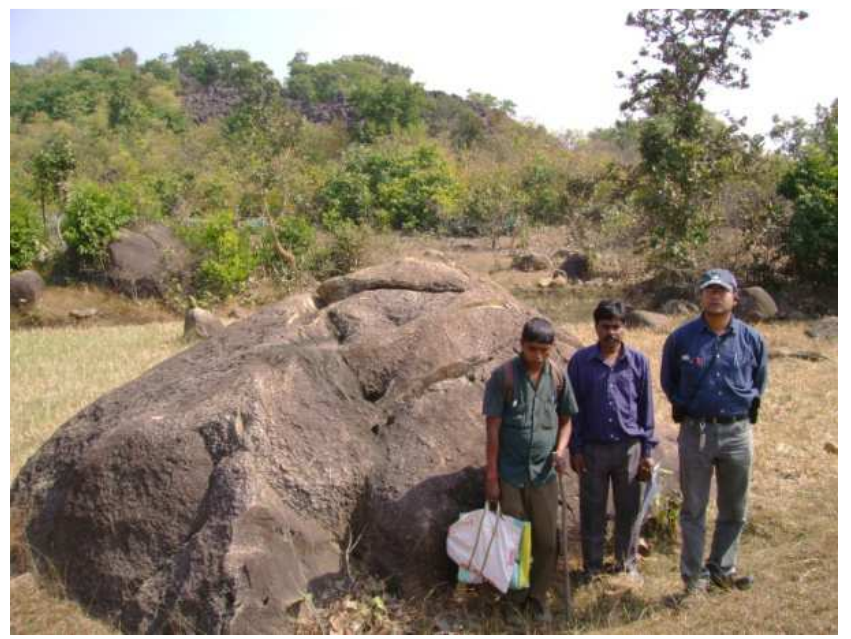

Fig. 6. Gabbroic exposure in Dublabera. 


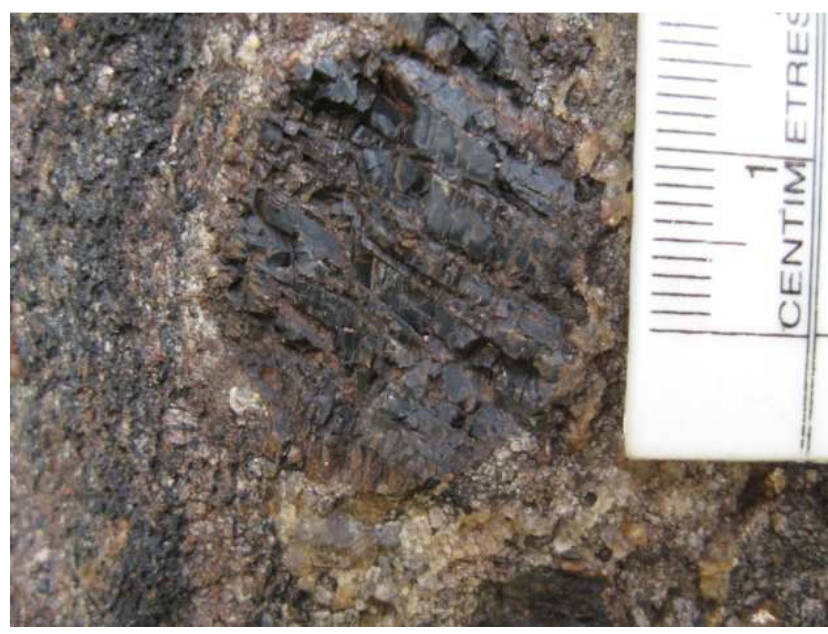

Fig 7. Fractured porphyroblast of magnetite showing reactionary margin with gabbroic host (Dublabera).

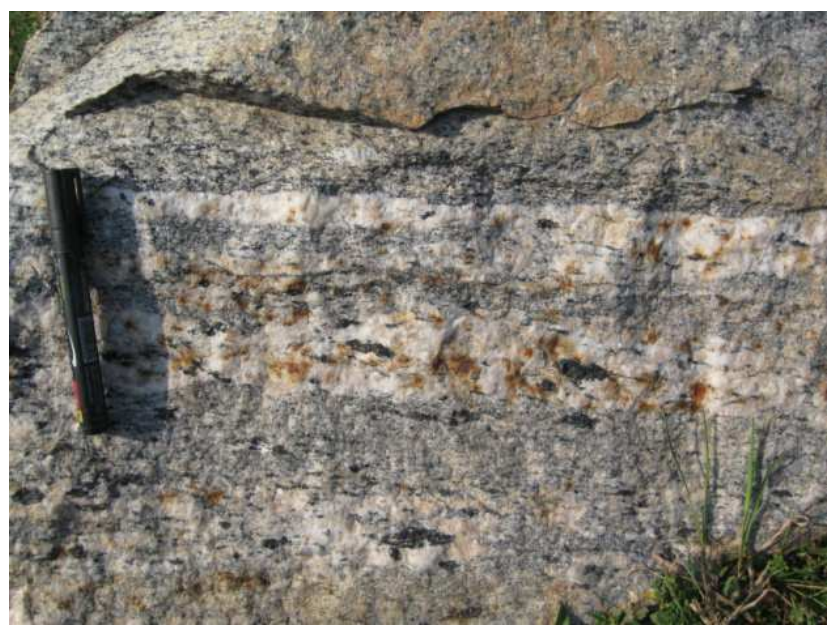

Fig. 8. Schlieren bands in granite-gneiss. The lighter bands contain lenticular magnetite (black) and garnet (brown). Kumhatdubi.

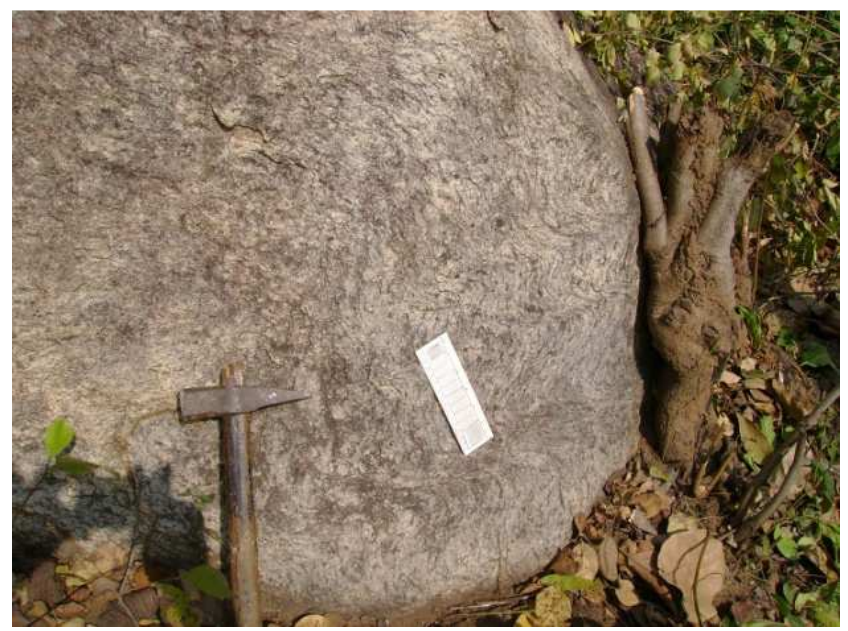

Fig. 9. Granite-gneiss showing puckering at Kumhardubi.

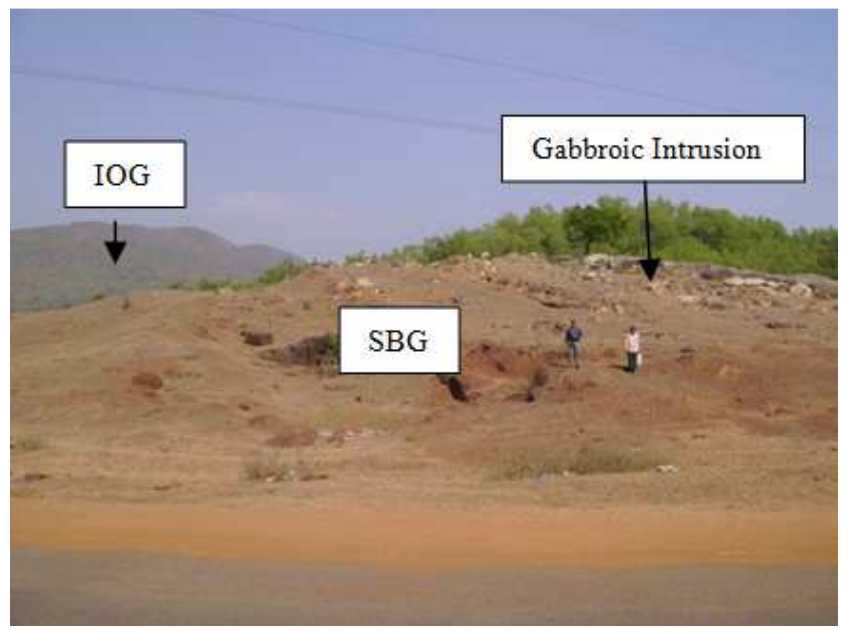

Fig. 10. Gabbroic inrusion within Singhbhum granite (SBG) associated with Iron Ore Group of rocks (IOG).

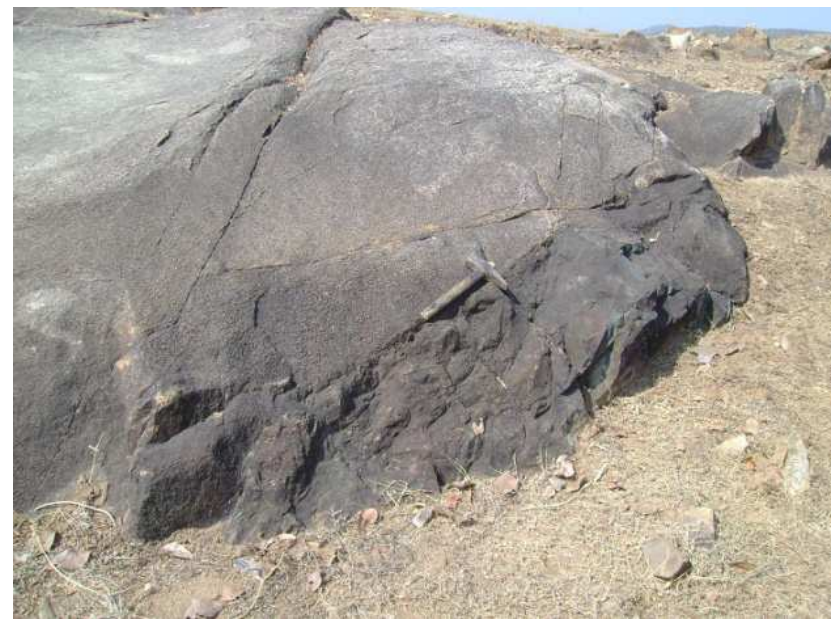

Fig. 11. Basic patch within granite-gneiss.

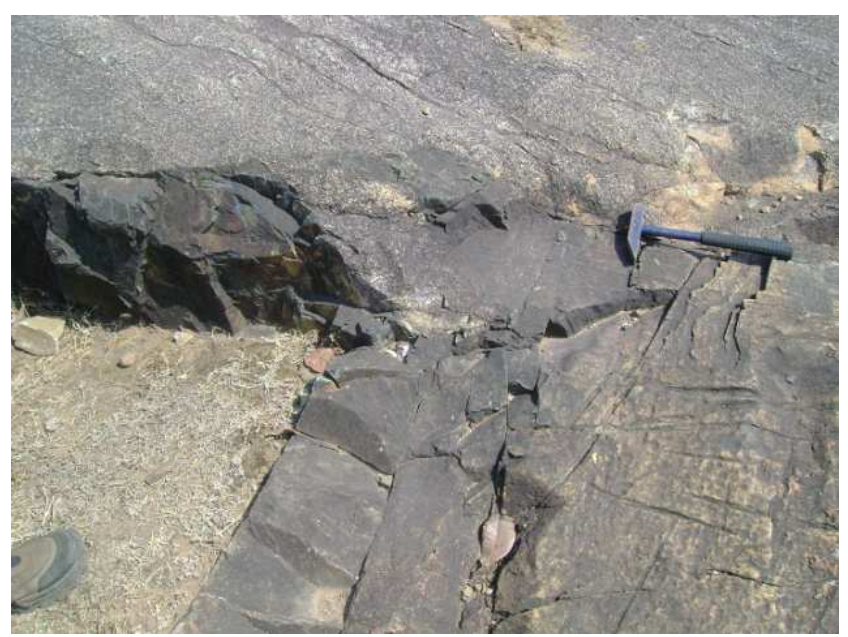

Fig. 12. Basic patch within granite-gneiss.

\section{Petrography of the Ores}

\subsection{Kumhardubi-Betjhran-Dublabera Ores}

The titaniferous magnetite bodies are mainly associated with gabbro-anorthositic rocks. Under microscope the 
gabbroic rocks are mainly composed of Plagioclase feldspar (oligoclase - andesine) and clinopyroxene (augite-titanaugite) with minor amounts of hypersthene, ferro-tremolite, biotite, chlorite, microcline feldspar, magnetite, sphene, ilmenite, hematite, spinel, rutile, actinolite, hornblende, epidote, zoisite, corundum, muscovite, chalcopyrite, pyrrhotite, chalcocite, covellite. Overall texture is coarse and massive retaining much of igneous texture and less metamorphic character. Grade of metamorphism in these rocks reach up-to amphibolite facies. Hypersthene and plagioclase feldspar show reaction relation with older clinopyroxene. Coarse to medium grained oxide minerals (magnetite, ilmenite) have reaction boundary with pyroxene (augite-titanaugite), amphibole (ferro-tremolite - hornblende) and biotite(Fig.33 \& Fig.34). Late generation oxide minerals replace earlier pyroxene (Fig.33). Besides gabbroic character, the host rock also shows granodioritic composition near the granitic contact. Under microscope this granodiorite shows metasomatic character due to effect of surrounding granite. Such textures include sodic plagioclase (oligoclase) enclosing small biotite, chlorite, muscovite; sieve texture shown by oligoclase and albite replacing microcline feldspar.

Microscopic study reveals that the ore is dominantly composed of magnetite, ilmenite, hematite, spinel and minor to trace amounts of rutile, chalcopyrite, chalcocite, covellite, pyrrhotite cobaltite, goethite, and silicate gangue. Dunn and Dey [15] reported presence of coulsonite in the titanomagnetite ores of Kumhardubi-Betjharan area. But controversy still exists in optical properties and composition of coulsonite in the ores (Roy [16]; Chakrobarty [17]; Das [18]). Overall the ores exhibit a polycrystalline granular texture. Coarse to medium polygonal magnetite grains are euhedral/subhedral in shape. Their grain boundaries tend to meet in triple junction points with an interfacial angle of $120^{\circ}$ The magnetite grains are preferentially martitized along grain boundary and octahedral planes (111) leaving unaltered core (Fig.13) except in few places where it is martitized throughout the grain. This martitization is caused by low temperature oxidation. Ilmenite occurs in four modes - a) as lamellae or blebs within magnetite host; b) as individual grain; c) within fracture filling veins and d) as intergrowth with hematite. Most of the magnetite grains contain lamellae or blebs of ilmenite along (111) and (100) planes (Fig.15) which resulted from the oxidation of exsolved ulvospinel (Fe2TiO4) which formed earlier by exsolution of titanomagnetite at higher temperature (Fig.38d shows the major Fe-Ti-O phases in the $\mathrm{FeO}-\mathrm{TiO} 2-\mathrm{Fe} 2 \mathrm{O} 3$ system). At temperature $7000-6000 \mathrm{C}$, titanomagnetite is exsolved into ulvospinel and magnetite where magnetite acts as the host and the lamellae of ulvospinel mainly follows the octahedral planes (111) and form the widmanstatten intergrowth. With decreasing temperature, ulvospinel becomes metastable and subsequently oxidized to ilmenite by reacting with available oxygen and $\mathrm{TiO} 2$. The reactions are as follows.

$$
\begin{array}{ccc}
3 \mathrm{Fe}_{2} \mathrm{TiO}_{4}+1 / 2 \mathrm{O}_{2}= & \mathrm{Fe}_{3} \mathrm{O}_{4}+3 \mathrm{Fe} \mathrm{Ti} \mathrm{O} \\
\text { Usp } & \mathrm{Mag} & \mathrm{Ilm}
\end{array}
$$

$$
\begin{array}{cc}
\mathrm{Fe}_{2} \mathrm{TiO}_{4} & \text { Usp } \\
\text { Ui O } & \text { Ilm }
\end{array}
$$

Haggerty [19] has shown that at C3 stage of oxidation, ulvospinel-poor magnetite solid solutions form densely crowded 'exsolved' ilmenite along (111) parting planes of the cubic host. Beside finer lamellae coarse lamellae of ilmenite is also observed within magnetite host. Thick ilmenite lamellae are seen to torn apart due to shearing effect (Fig.14). According to Dunn and Dey [15], coarse lamellae are the product of internal segregation after crystallization of the 'titanomagnetite' while the finer lamellae are formed when the latter becomes unstable at about the same time. They also stated a gradual concentration of titanium ions along certain planes during the cooling of original 'titanomagnetite' crystals without disturbing the cubic lattice and until a certain limiting value is reached. The cubic framework in these areas then contracts and rotates to give the framework of rhombohedral ilmenite. But according to present study, the coarser ilmenite lamellae are formed by oxidation of preexsolved ulvospinel lamellae with gradual enrichment of titanium ions along those planes (coalescing of primitive lamellas) by diffusion with increasing oxidation state.

Besides small lamellae or bands (trellis pattern) within magnetite, ilmenite also occurs as individual larger grains in the intergranular spaces or at the contact of the magnetite grains (Fig.19) and in fracture filling veins (Fig.13). These ilmenites are of younger generation formed during higher fO2 condition. Replacement texture is also observed where younger ilmenite grains replace magnetite grains along boundary. Occasionally relicts of small martitized magnetite grains are found within large ilmenite grain (Fig.20). Folded ilmenite grains, present in these ores, indicate ductile deformation (Fig.21). Besides the intergrowth of ilmenitemagnetite, hematite-ilmenite intergrowth is also formed which is preferentially seen to be oriented along the octahedral planes of titanomagnetite often having an outline of pre-exsolved ilmenite blebs (Fig.16). This type of texture is mainly formed at C4 stage of post 'exolution' oxidation when the ilmenite lamellae progressively decomposed to ferrian rutile + ferrian ilmenite and to rutile + Hemss (Haggerty [19]). The reaction is as follows.

$$
4 \mathrm{FeTiO}_{3}+\mathrm{O}_{2}=4 \mathrm{TiO}_{2}+2 \mathrm{Fe}_{2} \mathrm{O}_{3}
$$

Often thick ilmenite lamellae are seen to contain exsolved hematite lamellae (Fig.17). This texture is caused by exsolution of haemo-ilmenite into ilmenite and hematite at around $600 \mathrm{C}$. In few places, haphazard intergrowth between ilmenite and hematite are observed within altered titanomagnetite having no preferred orientation or outline (Fig.18). In these areas, earlier titanomagnetite is exsolved into rhombohedral phases of ilmenite and hematite at higher oxidation state with gradual decrease in temperature.

Spinel occurs both as lamellae and rounded to sub-rounded individual grains within altered magnetite grains (Fig.20 \& Fig.15). Plenty of sulfide minerals such as chalcopyrite, 
pyrrhotite, chalcocite, covellite and millerite occur in the ores (Fig.23 \& Fig.24). They are mostly present in the intergranular spaces or fractures of the large magnetite and ilmenite grains; sometimes concentrated in the hematiteilmenite intergrowth region. Folded chalcopyrite grains indicate post-crystallization deformation. In some places cobaltite is found to be mostly associated with sulfide grains (mainly chalcopyrite Fig.23) and silicate gangue. In the ores of Betjharan, large crystal of rutile containing small martitized magnetite is observed (Fig.22) Rutile shows reactive boundary with hematite which already has replaced earlier ilmenite. Presence of goethite vein indicates much later hydrothermal or weathering action. In these ores the magnetite grains show reaction relation with pyroxene and plagioclase feldspar (Fig.34). Amphiboles like ferro-tremolite or actinolite form at the boundary of pyroxene and opaque minerals (magnetite and ilmenite) (Fig.33 \& Fig.34)

\subsection{Nuasahi Ores}

In this area the titaniferous magnetite ores are mainly hosted by gabbro-anorthositic rocks. Coarse, polygonal, euhedral magnetite grains are rounded/sub-rounded and form interlocking texture in places (Fig.25). Under microscope pale brown titanomagnetite shows less no. of exsolved ilmenite lamellae along (111) and (100) planes. Less no. of ilmenite lamellae indicates their high formation temperature around $7500 \mathrm{C}$. Ilmenite also occurs as sub-rounded and subhedral discrete grains as well as fracture-filling bodies (Fig.29). Scattered magnetite grains within silicate gangue are frequent (Fig.26). Brecciated magnetite grains often show reaction relation with silicates. Martitization of magnetite is relatively low or moderate and mainly restricted at or near the ilmenite and silicate contacts (Fig.31). Martitization has also taken place along the crystallographic planes of magnetite. Martite often forms rim around magnetite (Fig.28). Martite shows sharp boundary with magnetite in a fault within magnetite indicating absence of reaction relation between them (Fig.27). This martite is formed from later introducing hydrothermal fluid rather than oxidation of magnetite. Mainly two generations of hematite are encountered. One generation involves elongated patches of hematite (Fig.28), synkinematicaly formed during shearing event and another is the hematite altered from magnetite. Numerous subhedral and anhedral grains of darker grey silicate minerals and spinel are poikilitically included within large magnetite grain(Fig.25\&27). Besides these, sulfide minerals like chalcopyrite, pyrrhotite, chalcocite, covellite and millerite are present. Small grains of chalcopyrite (mostly altered to chalcocite) are disseminated in martitized magnetite groundmass showing more or less sharp contact with the host. Sulfides are also enclosed within silicates (Fig.30) and often in ilmenites.

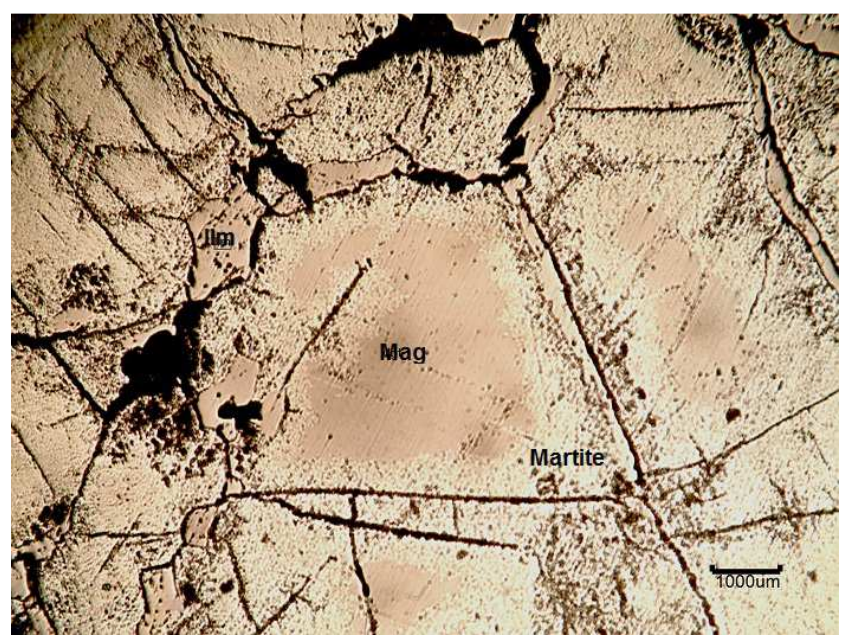

Fig. 13. Magnetite (Mag) grains are martitized along grain boundary leaving unaltered core. Ilmenite(Ilm) grains are present along fracture filling veins.

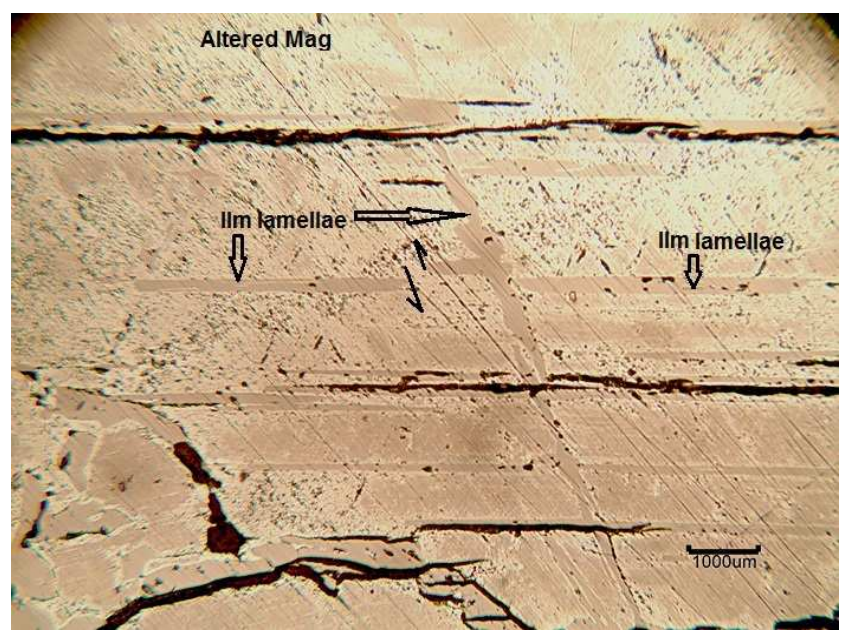

Fig. 14. Thick ilmenite lamellae are torn apart due to shearing effect.

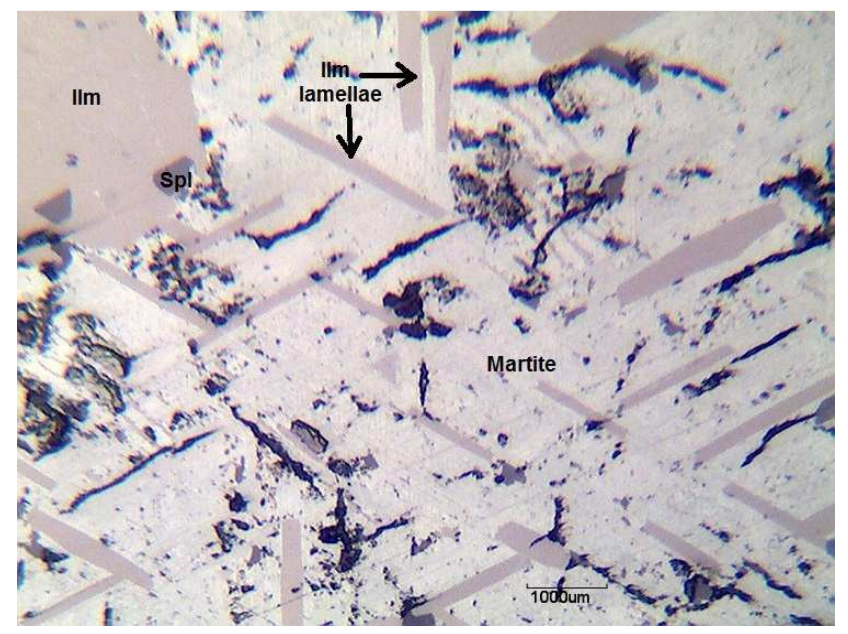

Fig. 15. Exsolved bodies of crystallographically oriented ilmenite (Ilm) (along (111) \& (100)) as well as well rounded ilmenite enclosed within extensively martitized magnetite groundmass. 


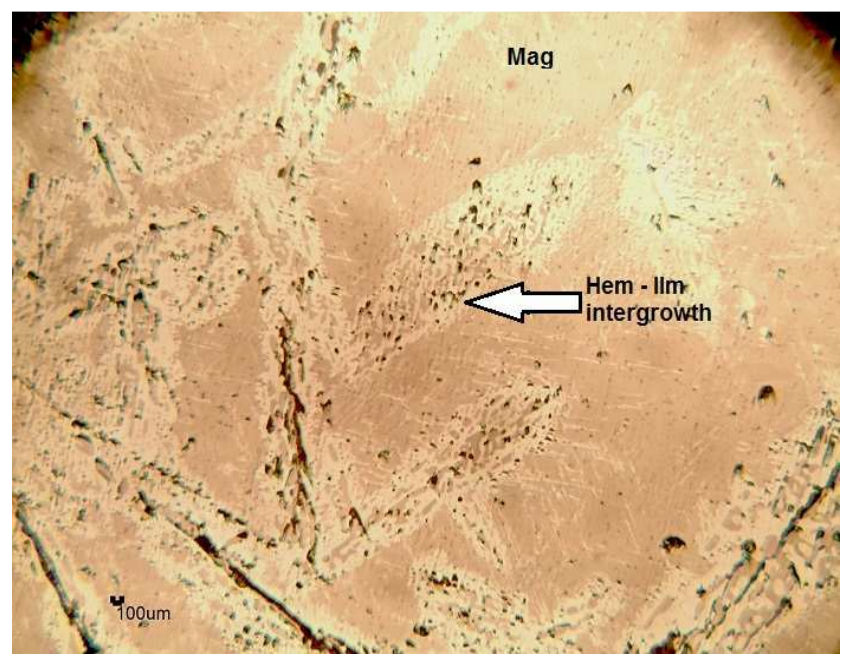

Fig. 16. Hematite (Hem)-ilmenite (Ilm) intergrowth oriented along octahedral planes (111) of titanomagnetite (Mag).

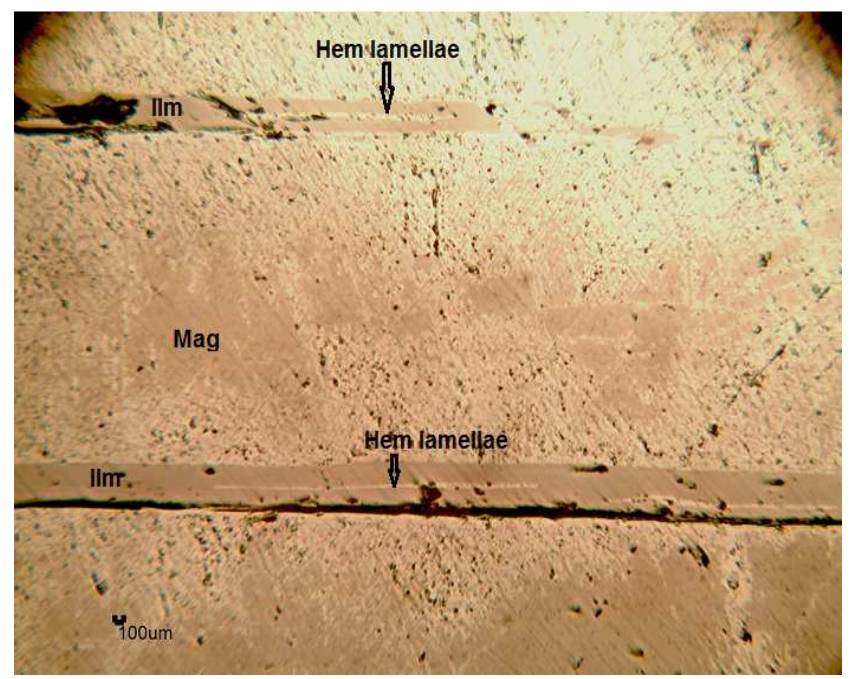

Fig. 17. Thick ilmenite (Ilm) lamellae containing exsolved hematite (Hem)lamellae.

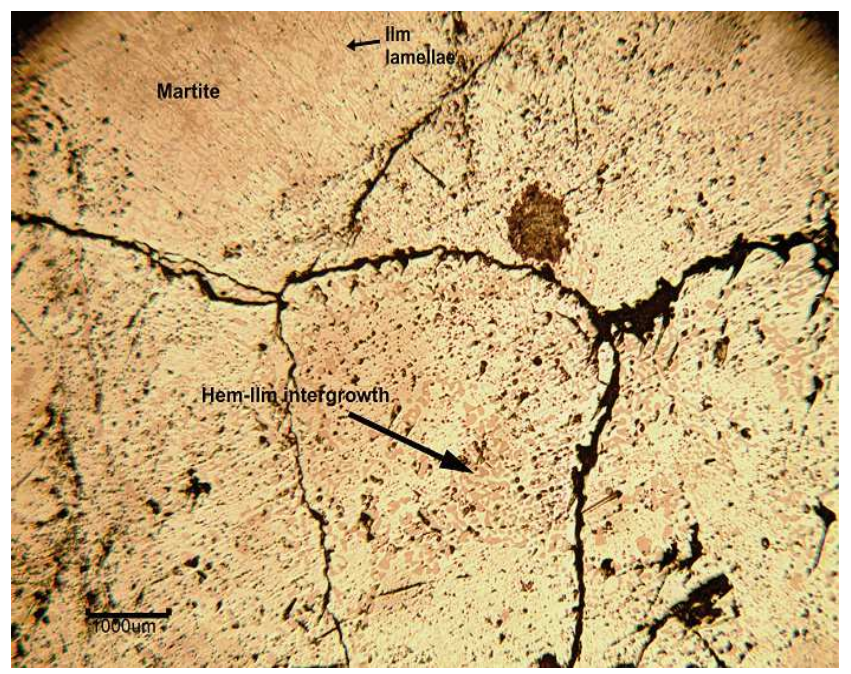

Fig. 18. Altered titanomagnetite containing haphazard intergrowth of hematite (Hem) - ilmenite (Ilm). Ilmenite lamellae are also present (at the top).

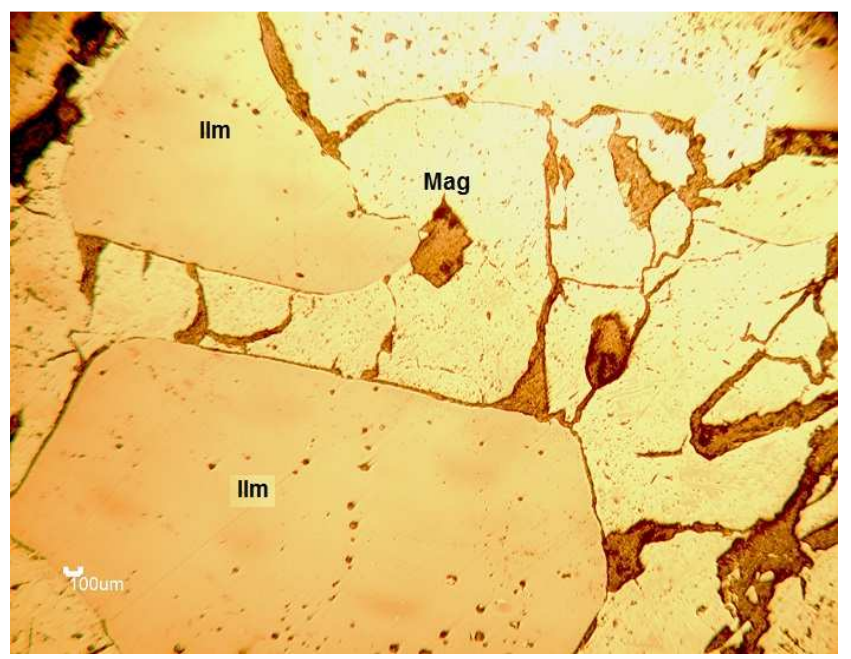

Fig. 19. Coarse ilmenite (Ilm) grains at the contact of magnetite (Mag) grains. Ilmenite is replacing magnetite.

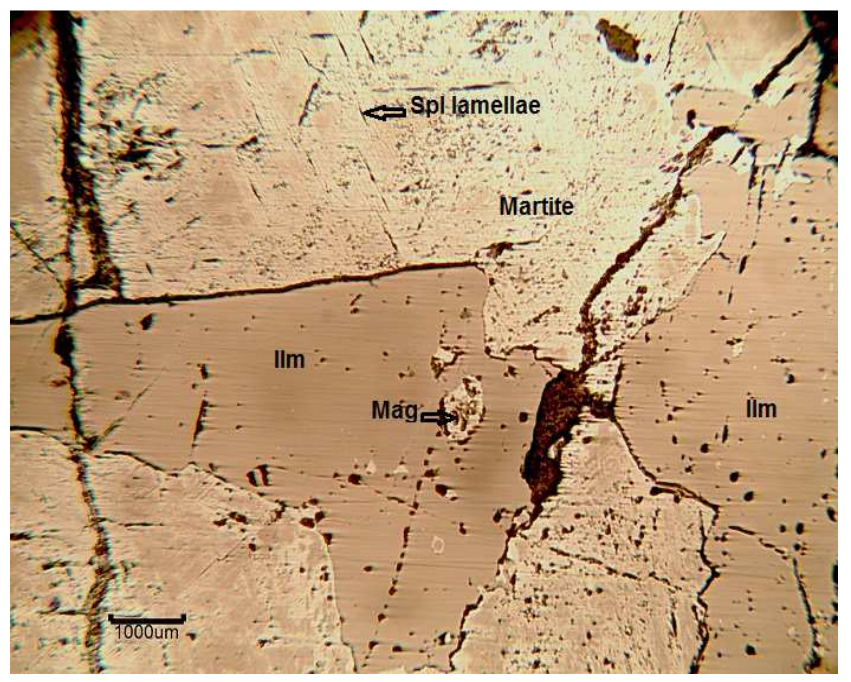

Fig. 20: Large ilmenite (Ilm) grain containing relict of earlier martitized magnetite (Mag) grain. Spinel (Spl) lamellae are present within altered magnetite grain (at the top).

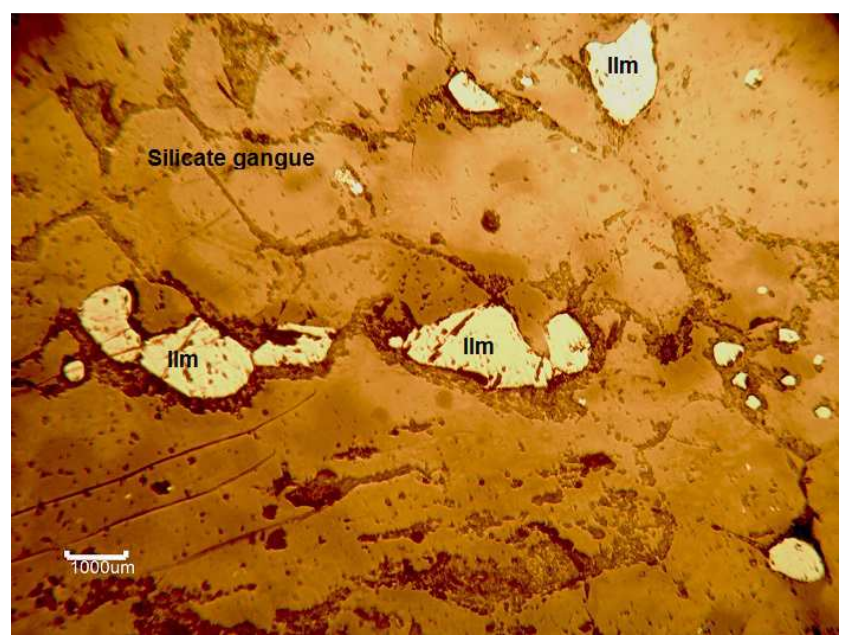

Fig. 21. Folded ilmenite (Ilm) grains within silicate gangue. 


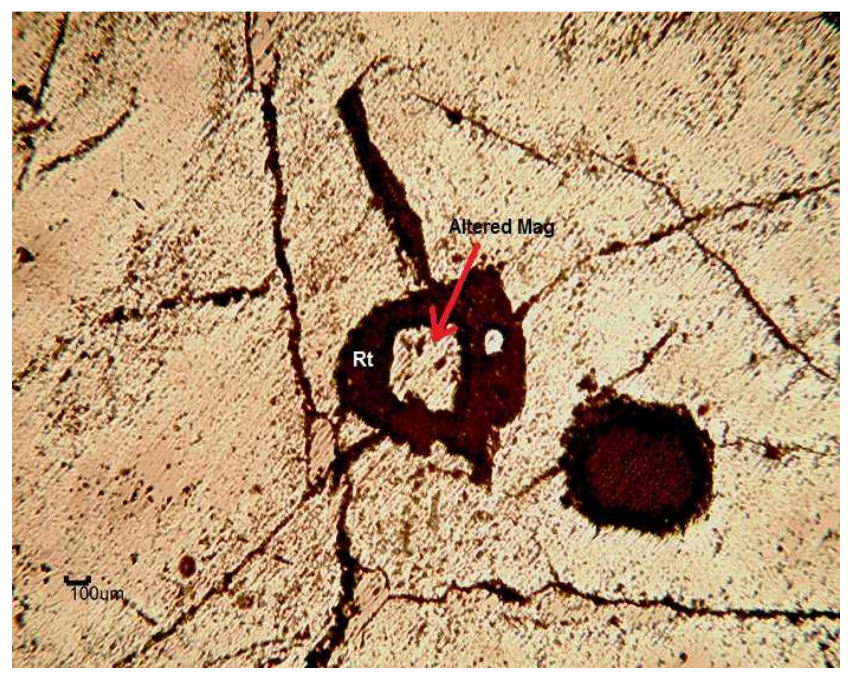

Fig. 22. Rutile (Rt) containing martitized magnetite (Mag) grain.

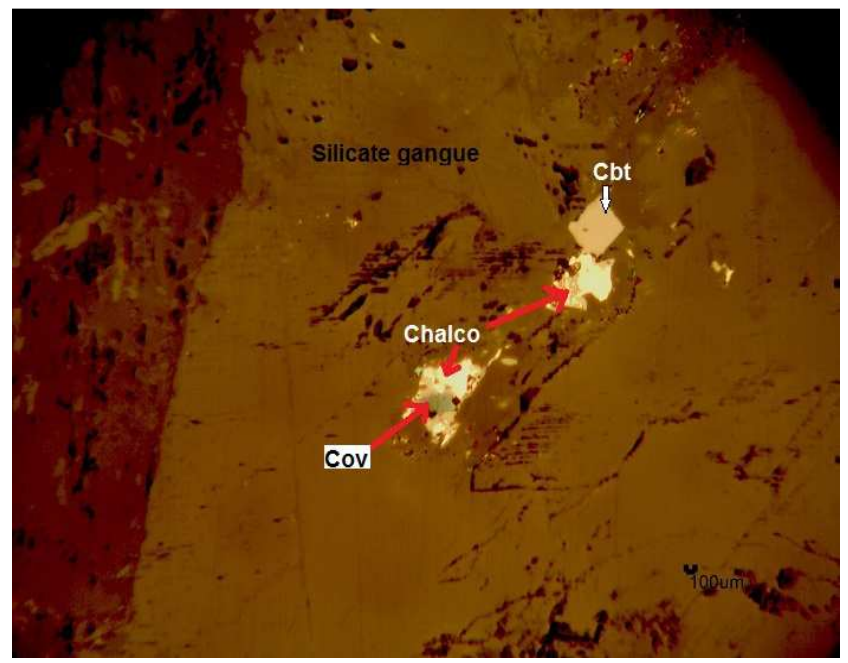

Fig. 23. Cobaltite (Cbt) associated with sulfide minerals (chalcopyrite (Chalco) \& covellite (Cov)) within silicate gangue.

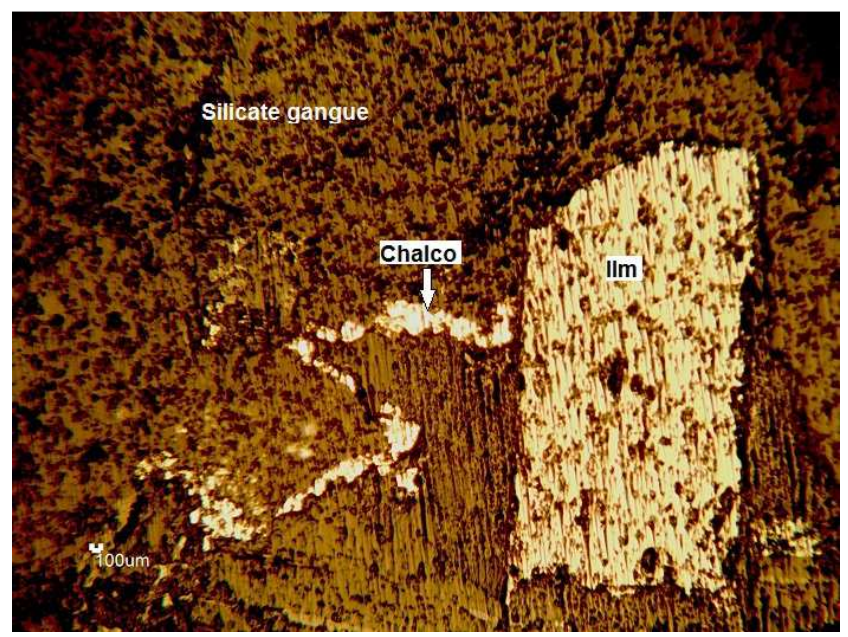

Fig. 24. Folded chalcopyrite (Chalco) grains associated with large ilmenite (Ilm) grain.

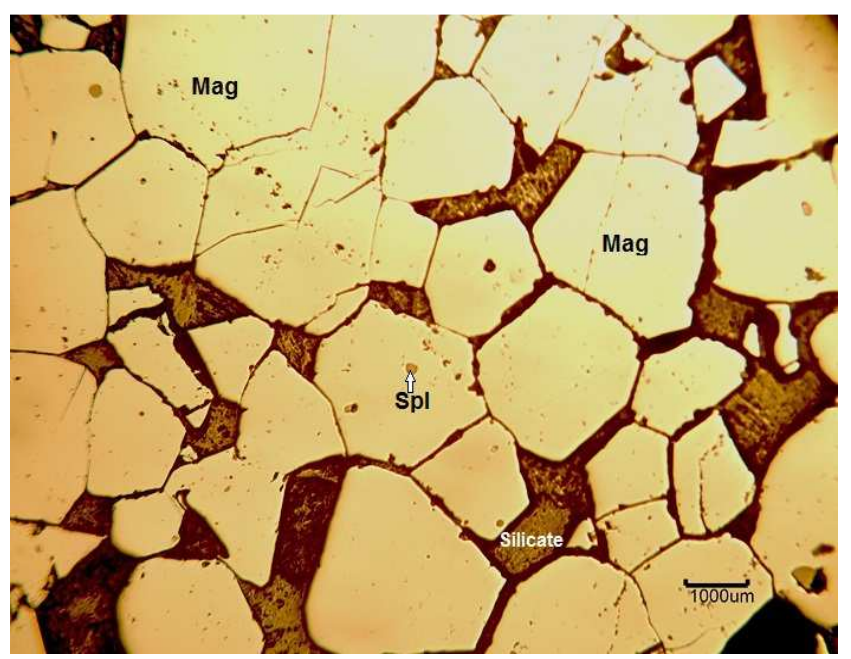

Fig. 25. Polygonal, euhedral magnetite (Mag) grains show interlocking texture. Rounded spinel grains (Sp) are present within magnetite grains.

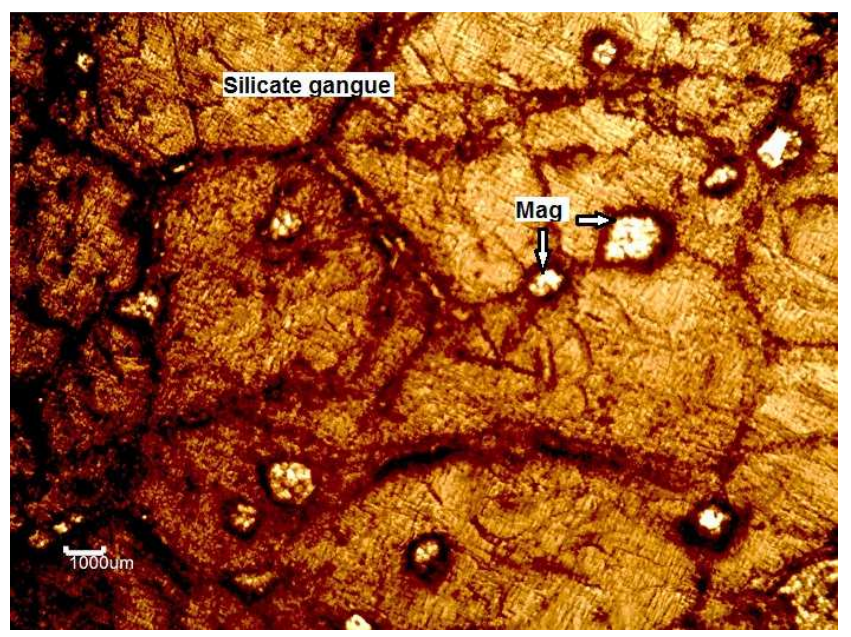

Fig. 26. Scattered magnetite (Mag) grains within silicate gangue.

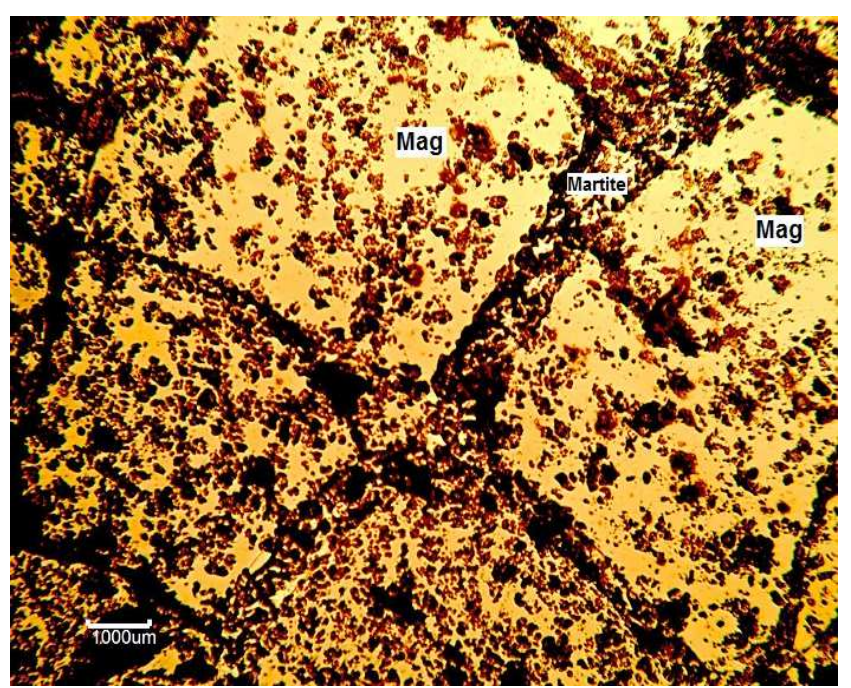

Fig. 27. Numerous silicate grains are included within large magnetite (Mag) grain. Martite shows sharp boundary with magnetite grains. 


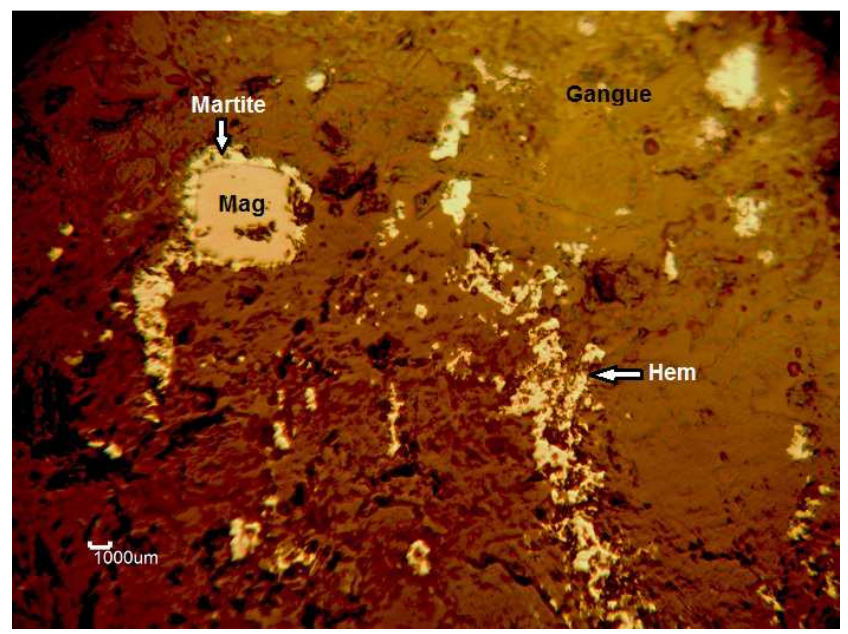

Fig. 28. Martite rim around magnetite (Mag) and elongated patch of hematite (Hem) within silicate gangue.

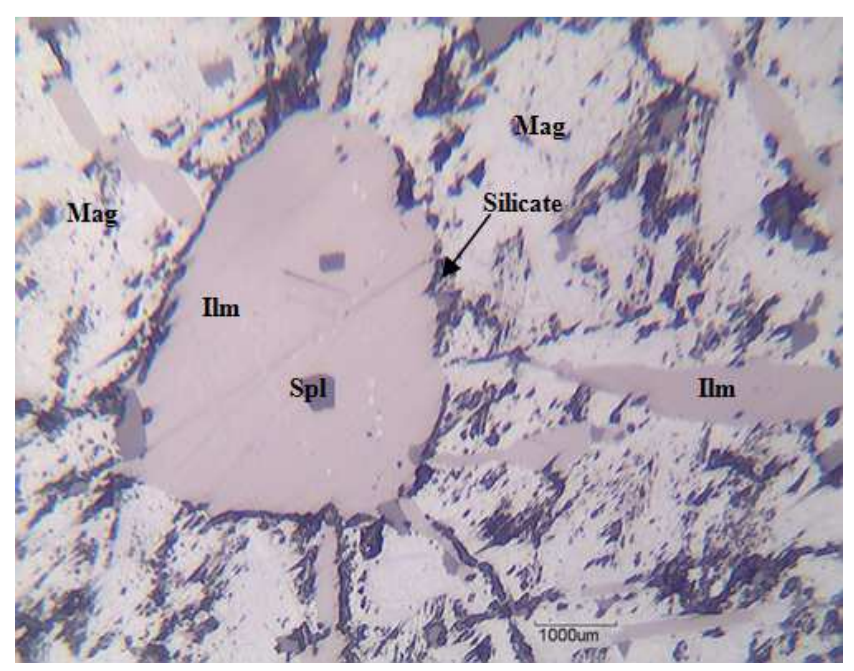

Fig. 29. Large sub-round ilmenite (Ilm) shows reaction relation with martitized magnetite. Dark silicate is formed at the contact. Exsolved lamellae of ilmenite also occur in magnetite groundmass.

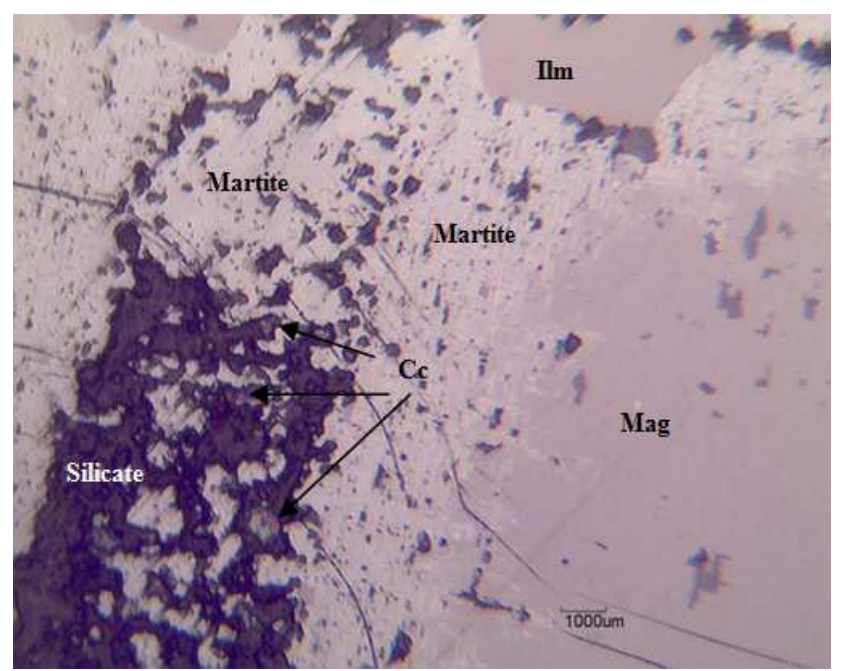

Fig. 30. Extensive reaction relation between silicate and magnetite. Martitization and sulfide (chalcocite (Cc)) are very prominent at the contact. Large subdedral ilmenite (Ilm) is enclosed within martitized magnetite.

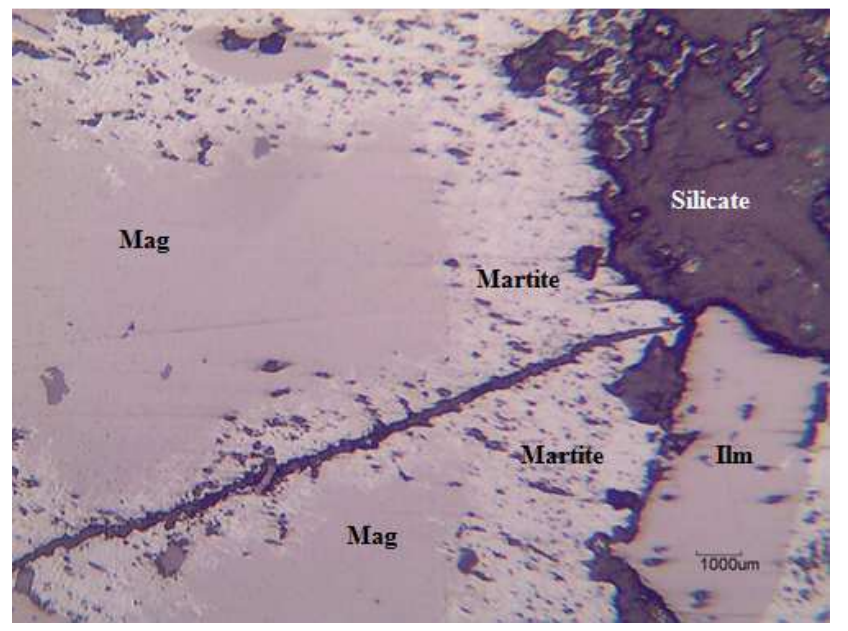

Fig. 31. Magnetite (Mag) shows extensive martitization at the silicate contact as well as along the fracture.

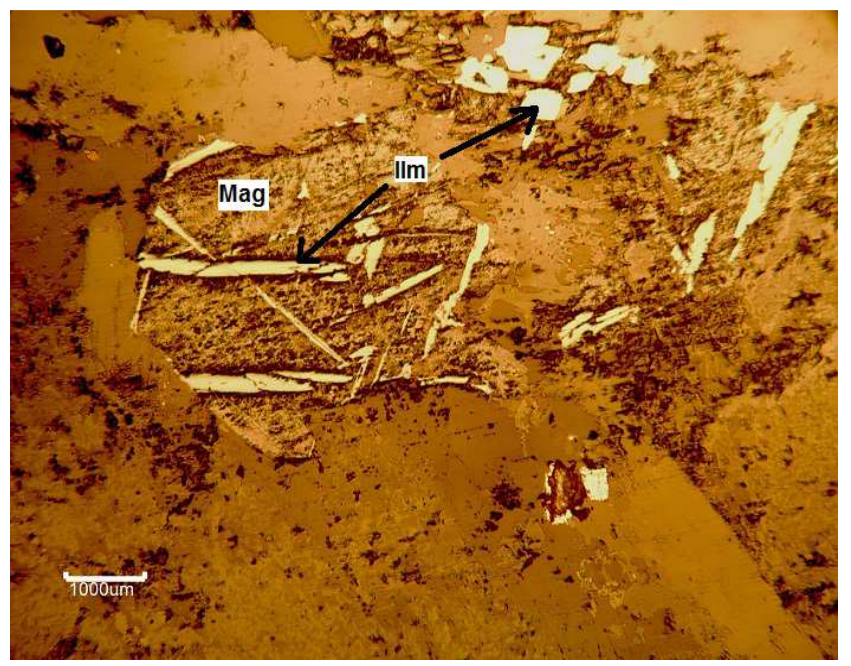

Fig. 32. Younger ilmenite(Ilm) replaces magnetite along weak planes. Subhedral ilmenite grains are also present within silicate gangue.

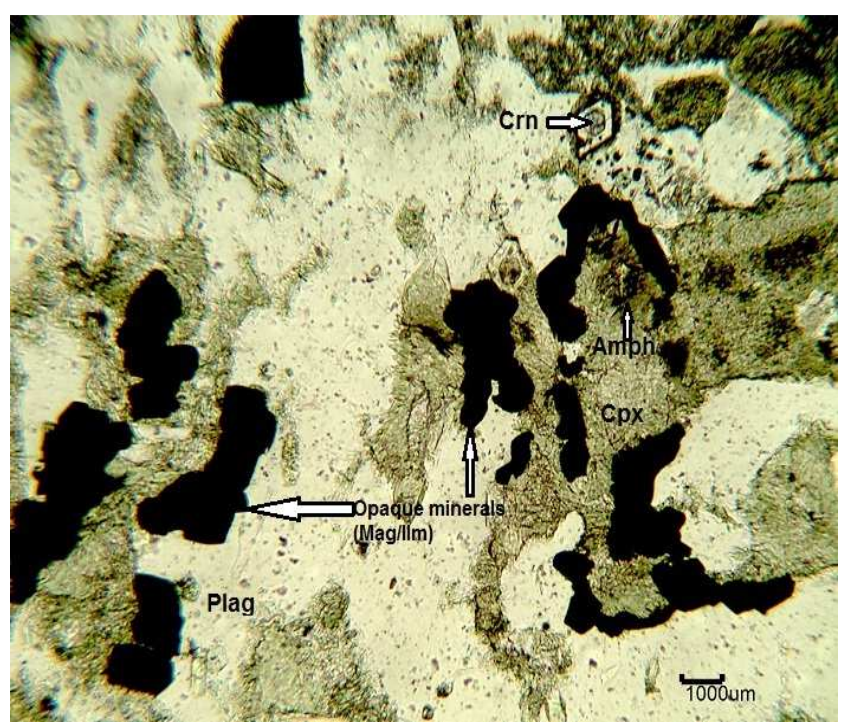

Fig. 33. Opaque minerals (Mag/Ilm) replace clinopyroxene (Cpx). Amphibole (Amph) forms at the contact. 


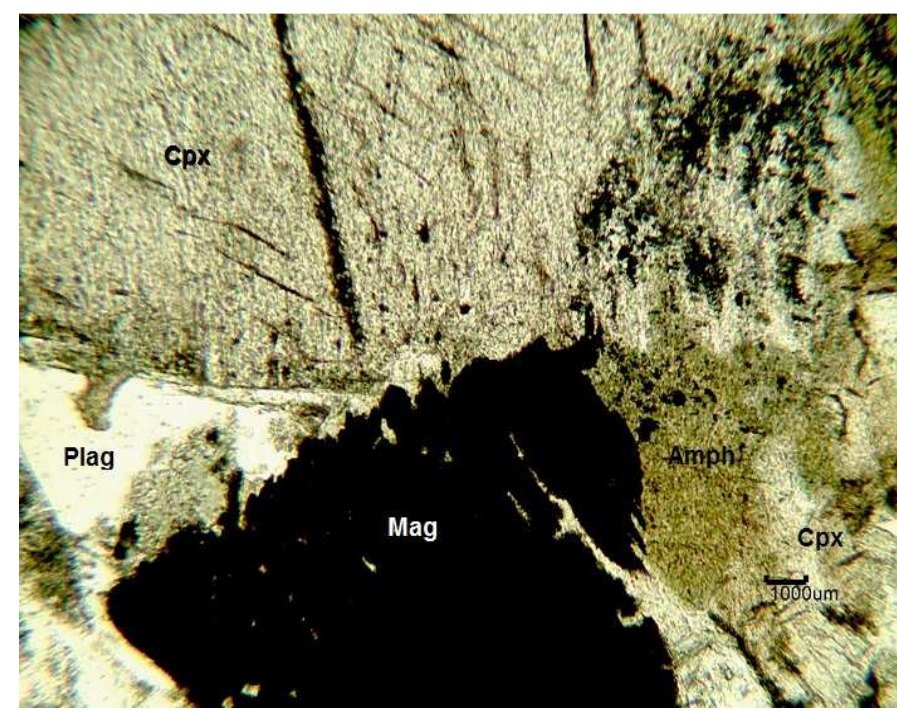

Fig. 34. Large magnetite shows reaction relation with clinopyroxene, (Cpx), amphibole (Amph) and plagioclase feldspar (Plag).

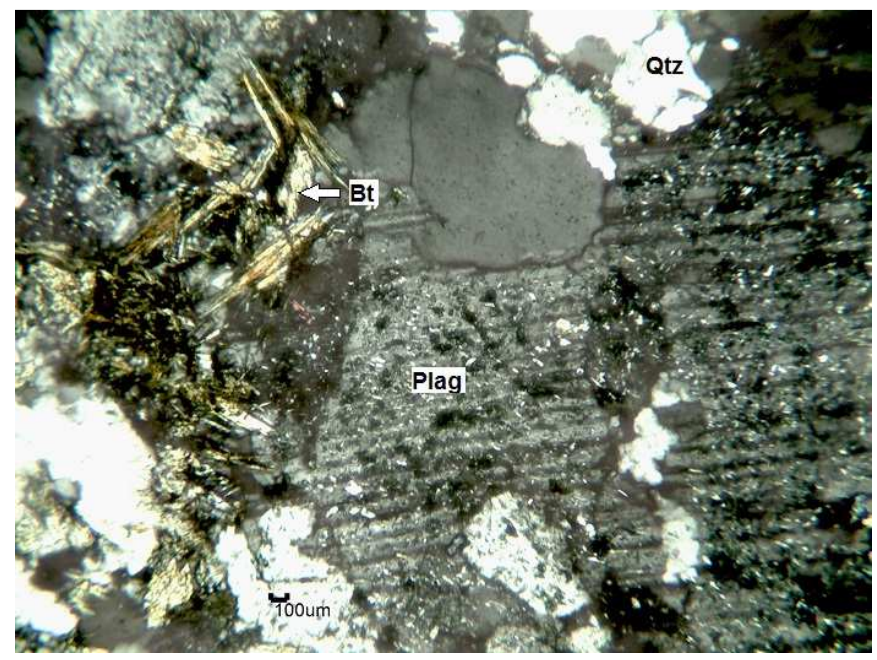

Fig. 35. Photomicrograph of deformed granite gneiss containing an assemblage of biotite (Bt), quartz (qtz) and saussuritized plagioclase feldspar (Plag)

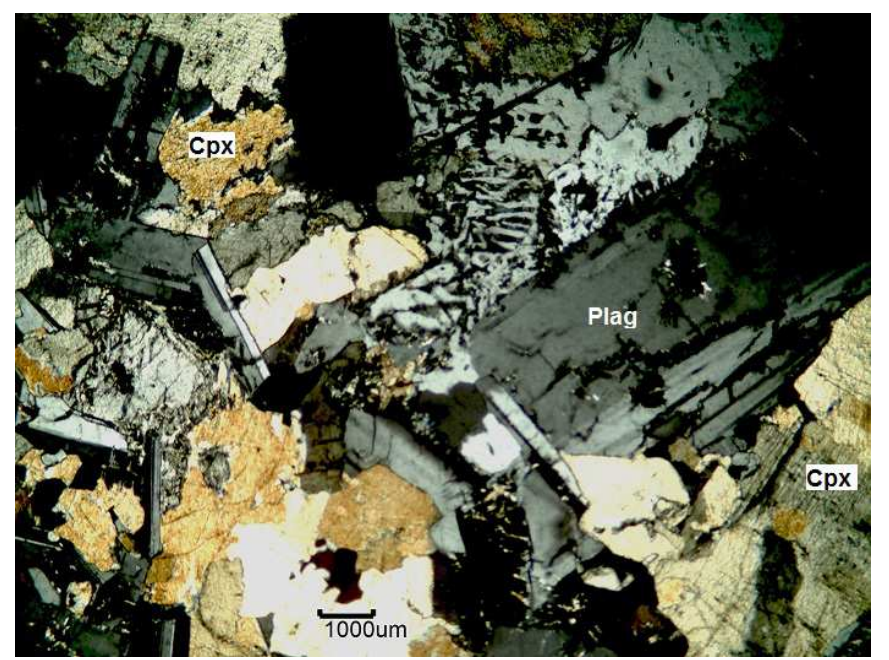

Fig. 36. Photomicrograph showing a typical assemblage of gabbroic rock.

\section{Mineral Chemistry of the Ore}

The chemical analysis of different minerals (magnetite, ilmenite and hercynite) of titaniferous magnetite ore of Kumhardubi-Betharan-Dublabera area is carried out by SEM-EDX technique. Major oxides of magnetite ores and host rocks of the aforesaid area are determined by XRF analyses whereas the same of Nuasahi area are analyzed by a combination of AAS and wet chemical method. The chemical analysis for minor and trace element contents in magnetite ores is done by ICP-OES method. The analytical data are presented in Table 2, 3, 4 \& 5 respectively. Different geochemical diagram are presented using these present analytical data. In addition, geochemical data of the same area given by other workers (Mohanty and Paul [20] and Das[21]) are also used in these diagrams.

In the bulk samples $\mathrm{TiO} 2$ and $\mathrm{V} 2 \mathrm{O} 3$ content varies from 10.35 to $17.68 \%$ and from 0.148 to $0.227 \%$ respectively. $\mathrm{Ti}$ and $\mathrm{V}$ contents of individual minerals like magnetite, ilmenite and hercynite show that besides magnetite, ilmenite is also vanadiferous ( $\mathrm{V}=0.09-0.12 \%)$. Besides these, the analytical values of individual minerals also reveal characteristic association of some other valuable metals like gold, platinum and zirconium. The concentration of $\mathrm{Fe} 2 \mathrm{O} 3$ in the ores varies between $32.75-67.39 \%$ whereas the $\mathrm{FeO}$ content ranges from 9.33 to $37.82 \%$. Higher $\mathrm{Fe} 2 \mathrm{O} 3$ content and low $\mathrm{FeO}$ content indicate higher oxidizing condition of the ores which is also evident in their petrography. Presence of variable amount of $\mathrm{SiO} 2$ is due to presence of very few silicate minerals. The ores contain less alumina (1.49 - 3.69\%) that's why the concentration of spinel is less. Maximum $\mathrm{CaO}$ and $\mathrm{MgO}$ values are 1.06 and 0.75 respectively. The $\mathrm{Fe} / \mathrm{Mg}$ plot (Fig.38a) shows that there is no preferred range of Fe$\mathrm{Mg}$ content in the ores rather they show variable range. In the $\mathrm{Fe} / \mathrm{Ti}$ plot (Fig.38b), the ores show high Ti content for moderate $\mathrm{Fe}$ content $(53-57 \%)$ whereas in the $\mathrm{Fe} / \mathrm{V}$ plot (Fig.38c), they show high V content for high Fe content (57$61 \%$ ). In the $\mathrm{FeO}-\mathrm{Fe} 2 \mathrm{O} 3-\mathrm{TiO} 2$ plot (Fig.38d), the ore samples mostly fall within the $\mathrm{Fe} 2 \mathrm{TiO} 4-\mathrm{Fe} 3 \mathrm{O} 4$ and $\mathrm{FeTiO} 3-$ $\mathrm{Fe} 2 \mathrm{O} 3$ joins i.e. within titanomagnetite and titanohematite solid solution lines. Plots in the MO-R2O3-TO2 diagram (Chevallier [22]) indicate that the ores fall in the field of titanomagnetite-II (Fig.38e) and are affected by late stage magmatic alteration. So, it can be concluded from the two ternary diagrams that the ores were originally crystallized as titanomagnetite and later suffered alteration with increasing oxidizing condition. Intense martitization of magnetite corroborates this. Under this condition ulvospinel oxidizes to ilmenite intergrowth within oxidized magnetite or martite. The plots near titanohematite solid solution line indicate presence of titanohematite which later get exsolved into hematite-ilmenite intergrowth at higher oxidation stage as found in the microscopic observation. 
Table 2. Analytical data of different minerals of Kumhardudi-Dublabera-Betjharan done by SEM-EDX (values range in wt \%).

\begin{tabular}{|c|c|c|c|c|c|c|c|c|c|c|}
\hline Mineral & O & Mg & Al & $\mathrm{Fe}$ & $\mathbf{T i}$ & V & $\mathrm{Cr}$ & $\mathbf{Z r}$ & $\mathbf{P t}$ & Au \\
\hline Magnetite & $\begin{array}{l}29.61- \\
33.61\end{array}$ & $\begin{array}{l}0.01- \\
0.18\end{array}$ & $\begin{array}{l}0.66- \\
1.12\end{array}$ & $\begin{array}{l}60.30- \\
68.48\end{array}$ & $\begin{array}{l}0.44 \\
3.95\end{array}$ & $\begin{array}{l}0.13- \\
0.66\end{array}$ & $\begin{array}{l}0.08- \\
0.22\end{array}$ & $\begin{array}{l}0.10- \\
0.85\end{array}$ & $\begin{array}{l}0.52- \\
0.94\end{array}$ & $\begin{array}{l}0.01- \\
0.02\end{array}$ \\
\hline Ilmenite & $\begin{array}{l}35.25- \\
40.15\end{array}$ & $\begin{array}{l}0.74- \\
1.09\end{array}$ & $\begin{array}{c}0.04- \\
0.17\end{array}$ & $\begin{array}{l}24.98- \\
31.79\end{array}$ & $\begin{array}{l}22.14- \\
28.85\end{array}$ & $\begin{array}{l}0.09- \\
0.12\end{array}$ & $\begin{array}{l}0.05- \\
0.30\end{array}$ & $\begin{array}{l}0.02- \\
1.35\end{array}$ & $\begin{array}{l}0.34- \\
11.60\end{array}$ & $\begin{array}{l}0.01- \\
0.26\end{array}$ \\
\hline Hercynite & $\begin{array}{l}39.58- \\
43.81\end{array}$ & $\begin{array}{l}5.91- \\
6.55\end{array}$ & $\begin{array}{l}28.77- \\
30.94\end{array}$ & $\begin{array}{l}19.76- \\
20.98\end{array}$ & $\begin{array}{l}0.08 \\
0.19\end{array}$ & $\begin{array}{ll}-\quad 0.01- \\
0.18\end{array}$ & $\begin{array}{l}0.03- \\
0.31\end{array}$ & $\begin{array}{l}0.03- \\
1.37\end{array}$ & $\begin{array}{l}0.23- \\
2.89\end{array}$ & $\begin{array}{l}0.14- \\
0.30\end{array}$ \\
\hline
\end{tabular}

Table 3. Major oxides contents (wt \%) of magnetite ores and host rocks of Kumhardudi-Dublabera-Betjharan from chemical analysis by XRF.

\begin{tabular}{|c|c|c|c|c|c|c|c|c|c|c|c|}
\hline Sample type & $\mathrm{SiO}_{2}$ & $\mathrm{Fe}_{2} \mathrm{O}_{3}$ & $\mathrm{Al}_{2} \mathrm{O}_{3}$ & $\mathrm{CaO}$ & MgO & $\mathrm{Na}_{2} \mathrm{O}$ & $\mathrm{K}_{2} \mathrm{O}$ & $\mathrm{TiO}_{2}$ & $\mathrm{P}_{2} \mathrm{O}_{5}$ & $\mathrm{~V}_{2} \mathrm{O}_{3}$ & $\mathrm{FeO}$ \\
\hline Magnetite Ore & $\begin{array}{l}1.33- \\
2.33\end{array}$ & $\begin{array}{l}32.75- \\
51.59\end{array}$ & $\begin{array}{l}3.02- \\
3.69\end{array}$ & $\begin{array}{l}0.75- \\
1.06\end{array}$ & $\begin{array}{l}0.57- \\
0.75\end{array}$ & $\begin{array}{l}0.002- \\
0.003\end{array}$ & $\begin{array}{l}0.007- \\
0.01\end{array}$ & $\begin{array}{l}10.35- \\
17.68\end{array}$ & $\begin{array}{l}0.04- \\
0.13\end{array}$ & $\begin{array}{l}0.148- \\
0.206\end{array}$ & $\begin{array}{l}16.79- \\
37.82\end{array}$ \\
\hline Host Rock & $\begin{array}{l}50.01- \\
67.48\end{array}$ & $\begin{array}{l}2.95- \\
8.69\end{array}$ & $\begin{array}{l}13.98- \\
16.28\end{array}$ & $\begin{array}{l}2.59- \\
5.39\end{array}$ & $\begin{array}{l}2.12- \\
3.64\end{array}$ & $\begin{array}{l}1.77- \\
4.20\end{array}$ & $\begin{array}{l}0.97- \\
2.09\end{array}$ & $\begin{array}{l}0.35- \\
1.97\end{array}$ & $\begin{array}{l}0.19- \\
0.43\end{array}$ & $\begin{array}{l}0.0031- \\
0.044\end{array}$ & $\begin{array}{l}2.77- \\
1.86\end{array}$ \\
\hline
\end{tabular}

Table 4. Major oxides contents (wt \%) of magnetite ores of Baula-Nuasahi from chemical analysis by AAS \& wet chemical (combined).

\begin{tabular}{lllllll}
\hline Sample no. & $\mathbf{S i O}_{2}$ & $\mathbf{F e}_{\mathbf{2}} \mathbf{O}_{\mathbf{3}}$ & $\mathbf{A l}_{\mathbf{2}} \mathbf{O}_{\mathbf{3}}$ & $\mathbf{T i O}_{\mathbf{2}}$ & $\mathbf{F e O}_{\mathbf{2}} \mathbf{O}_{\mathbf{3}}$ & \\
\hline Nua-M1 & 16.11 & 46.31 & 3.02 & 11.32 & 21.08 & 0.227 \\
Nua-M2 & 9.26 & 45.62 & 2.63 & 11.79 & 29.72 \\
Nua-M3 & 5.28 & 67.39 & 1.49 & 12.17 & 0.163 & 9.33 \\
\hline
\end{tabular}

Table 5. Minor and Trace element contents (in ppm) of magnetite ores and host rocks of Kumhardudi-Dublabera-Betjharan from chemical analysis by ICP OES.

\begin{tabular}{|c|c|c|c|c|c|c|c|c|c|c|c|c|c|c|c|c|}
\hline $\begin{array}{l}\text { Sample } \\
\text { type }\end{array}$ & $\mathbf{C u}$ & $\mathbf{P b}$ & Zn & $\mathrm{Ni}$ & Co & $\mathbf{B a}$ & $\mathrm{Sr}$ & $\mathbf{Z r}$ & $\mathrm{Cr}$ & Sc & $\mathbf{V}$ & $\mathrm{Ce}$ & $\mathbf{L a}$ & Nd & Pr & Sm \\
\hline $\begin{array}{l}\text { Magnetite } \\
\text { Ore }\end{array}$ & N.D. & $\begin{array}{l}41- \\
46.34\end{array}$ & 300 & $\begin{array}{l}51- \\
100\end{array}$ & 300 & $\begin{array}{l}21.5- \\
100\end{array}$ & $\begin{array}{l}4.9- \\
44.68\end{array}$ & $\begin{array}{l}33.12 \\
-40.3\end{array}$ & $\begin{array}{l}100- \\
200\end{array}$ & $\begin{array}{l}38- \\
41\end{array}$ & $\begin{array}{l}1000- \\
1400\end{array}$ & $\begin{array}{l}0.45- \\
60.33\end{array}$ & $\begin{array}{l}0.68- \\
90\end{array}$ & 16.42 & 0.32 & 0.32 \\
\hline $\begin{array}{l}\text { Host } \\
\text { Rock }\end{array}$ & $\begin{array}{l}11.1- \\
200\end{array}$ & $\begin{array}{l}1.28- \\
3.5\end{array}$ & $\begin{array}{l}130- \\
200\end{array}$ & $\begin{array}{l}15.1 \\
-200\end{array}$ & $\begin{array}{l}9.8- \\
77.34\end{array}$ & $\begin{array}{l}80.6- \\
200\end{array}$ & $\begin{array}{l}100- \\
300\end{array}$ & $\begin{array}{l}55- \\
62.35\end{array}$ & $\begin{array}{r}41.10 \\
-300\end{array}$ & $\begin{array}{l}2.22 \\
-29\end{array}$ & $\begin{array}{l}21.4- \\
300\end{array}$ & $\begin{array}{l}11.57 \\
-6.59\end{array}$ & $\begin{array}{l}4.02- \\
6.64\end{array}$ & $\begin{array}{l}2.69- \\
4.11\end{array}$ & 7.1 & 3 \\
\hline
\end{tabular}

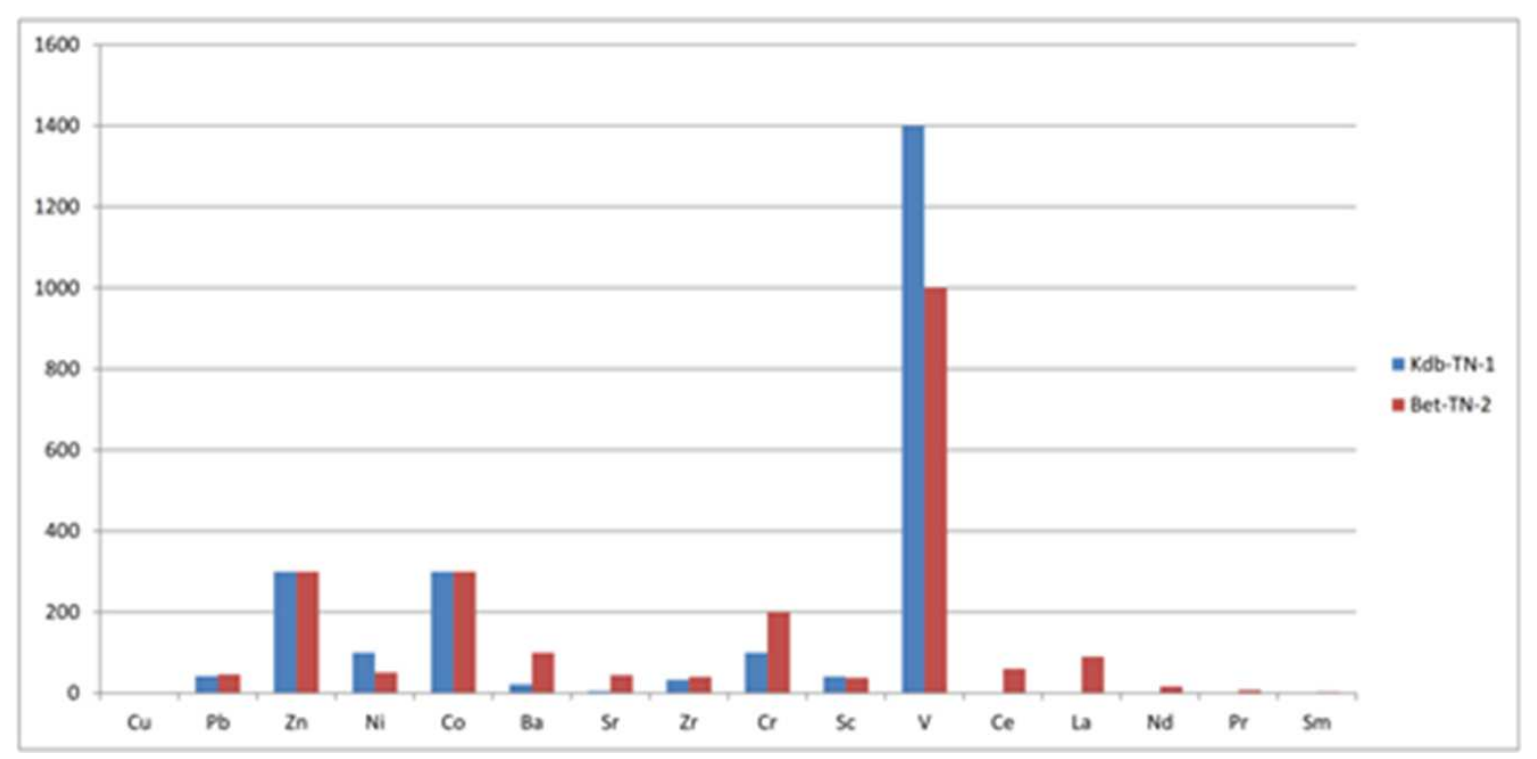

Fig. 37. Graphical representation of elemental concentration of different minor and trace element within the magnetite ores. 
a.

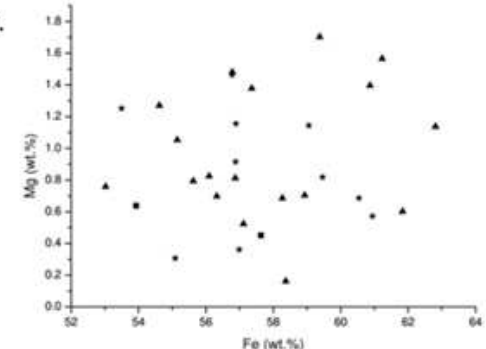

c.

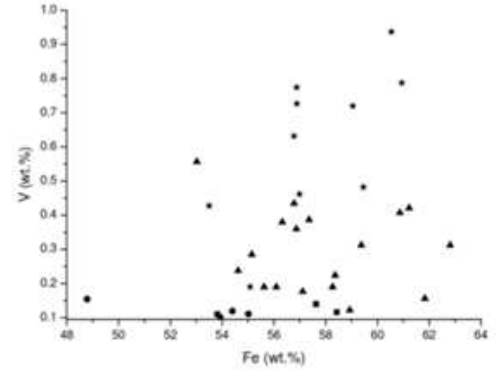

b.

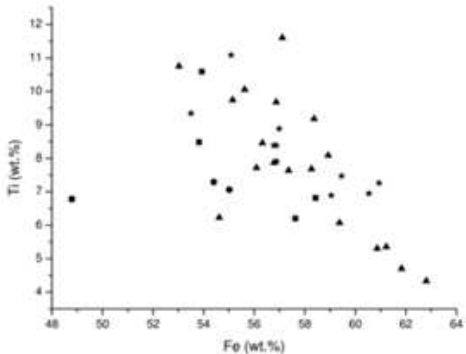

d.

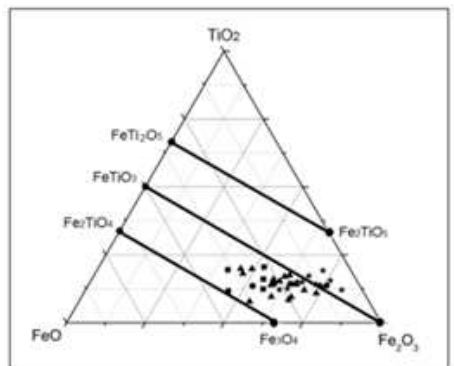

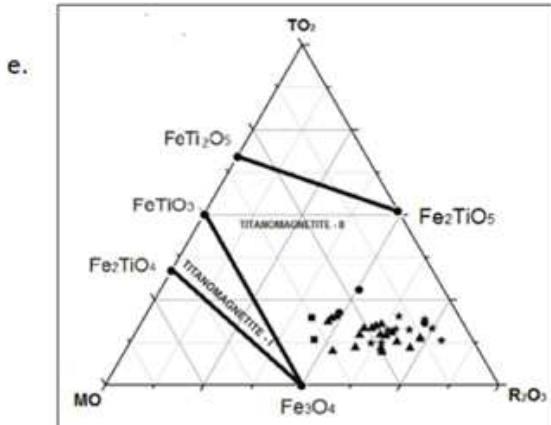

Fig. 38. Geochemical diagrams using analytical data of the magnetite ore. a. $\mathrm{Fe} / \mathrm{Mg}$ plot. b. Fe/Ti plot. c. Fe/V plot. d. FeO-Fe $\mathrm{O}_{3}$-TiO ${ }_{2}$ plot e. Classification diagram of titanomagnetite ore. $\left(\mathrm{MO}=\mathrm{FeO}+\mathrm{MgO} ; \mathrm{R}_{2} \mathrm{O}_{3}=\mathrm{Fe}_{2} \mathrm{O}_{3}+\mathrm{Al}_{2} \mathrm{O}_{3}+\mathrm{V}_{2} \mathrm{O}_{3} ; \mathrm{TO}_{2}=\mathrm{TiO}_{2}+\mathrm{SiO}_{2}\right)$.

$=$ Samples of Kumhardubi-Dublabera-Betjharan of present study area.

Samples of Nuasahi of present study area

= Samples of Nuasahi after Mohanty\& Paul, 2008

= Samples of Mayurbhanj igneous complex after Das, 2014.

Fig.37 is the graphical representation of elemental concentration of the different minor and trace elements taken from Table 4. It is evident that concentrations of $\mathrm{V}, \mathrm{Co}, \mathrm{Zn}$, and $\mathrm{Cr}$ are relatively high. The $\mathrm{Co} / \mathrm{Ni}$ ratio and the contents of the $\mathrm{Cr}$ and $\mathrm{Ti}$ can be used to differentiate between igneous and sedimentary origin of magnetite. According to Frietsch [23], $\mathrm{Co} / \mathrm{Ni}$ ratio is below unity for iron oxides of low temperature and sedimentary origin but is higher than unity for iron oxides of igneous origin. The $\mathrm{Co} / \mathrm{Ni}$ ratio of the magnetite ore samples in the present area ranges from 3 to 5.88 which thus clearly indicates the igneous origin. In addition to this, the higher concentrations of $\mathrm{Cr}$ (100-200 ppm) and Ti (6.199-10.59 wt. \%), which are well above the Clarke values (110 and 1000 ppm respectively) of sediment, also attest to the igneous origin. The average values of $\mathrm{Ni}$ in igneous rocks are 80 to $200 \mathrm{ppm}$ (Shaw [24]). In this ore maximum Ni content is $100 \mathrm{ppm}$. This further supports the igneous origin. Higher concentrations of $\mathrm{V}$, Ti $\mathrm{Zn}, \mathrm{Cr}, \mathrm{Co}$, Sc in these ores than those in other iron ore deposits suggest the importance of these titaniferous magnetites for the recovery of such valuable metals by metallurgical processes.

The characteristics of the host rocks are obtained from different classification diagram. The $\mathrm{SiO} 2-\mathrm{Na} 2 \mathrm{O}+\mathrm{K} 2 \mathrm{O}$ plot (Fig.39a) of Middlemost [25] and Total Alkali Saturation (TAS) plot (Fig.39b) of Cox [26] show that the host rock composition is similar to gabbro mainly and it is granodioritic in few places mainly near the contact with associated granite. The $\mathrm{SiO} 2-\mathrm{FeOt} / \mathrm{MgO}$ plots (Fig.39c) of Miyashiro [27] indicate the tholeiitic character of the gabbroic rock and calc-alkaline character of the granodioritic rock. This is also evident in the AFM plot (Fig.39d) of Irvine and Baragar [28]. AFM plot also shows very high iron-oxide content of the host rock of Nuasahi area. The Ti/V plot (Fig.39e) of Shervais [29] gives an idea of the prevailing 
geotectonic set-up during formation of the mafic-ultramafic
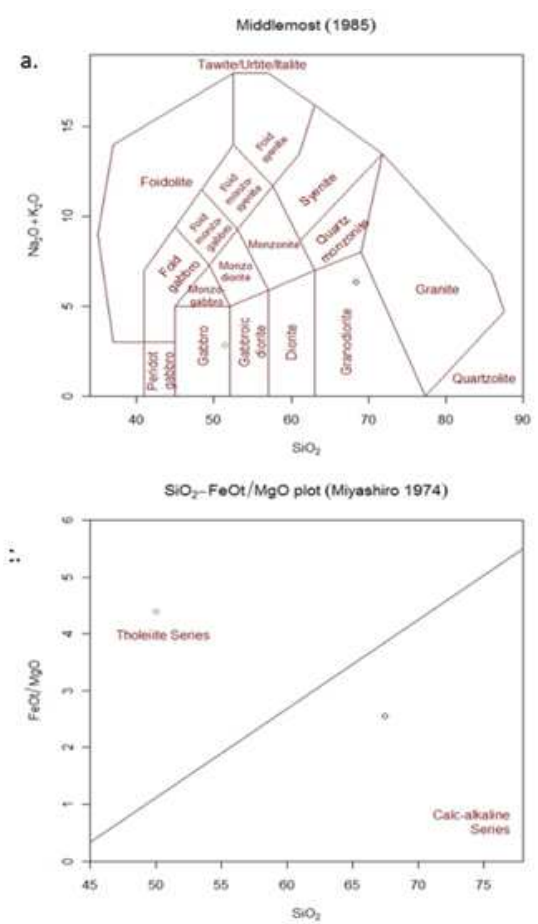

complex.

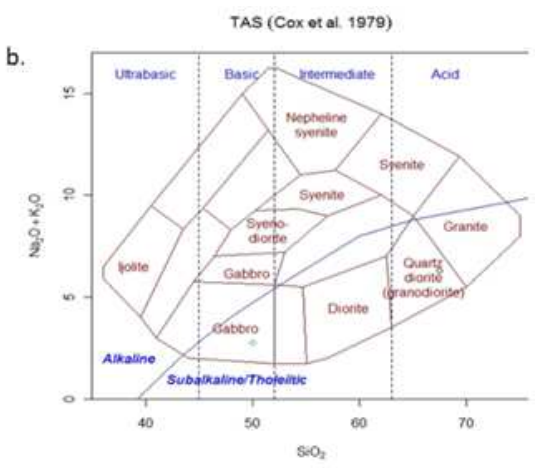

$$
\text { AFM plot (Irvine and Baragar 1971) }
$$

d.

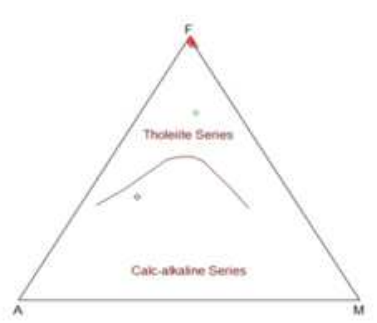

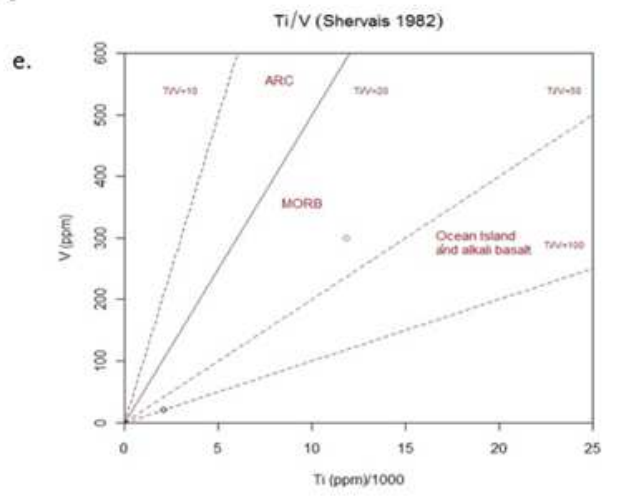

Fig. 39. Geochemical diagrams (plotted by using GCD kit software) characterize the host rocks of the present study area.

\section{Paragenesis}

From detailed microscopic study and geochemistry, it is evident that the magnetite ores are titaniferous and vanadiferous and their composition mainly belong to the ulvospinel-magnetite join and a little above it following the oxidation trend. At first, the titanomagnetite crystallized by magmatic process which exsolved into ulvospinel (lamellae) and magnetite (host) at around 7000-6000C temperature. Ulvospinel being metastable oxidized to ilmenite with decreasing temperature. The ilmenite lamellae within magnetite host are formed by this process. An enrichment of Ti ions along certain octahedral planes and coalescing of early lamellae cause the ilmenite lamellae to be thicker with increasing oxidation condition. Then the ilmenite lamellae (compositionally hemo-ilmenite) exsolved to hematite (lamellae) and ilmenite (host) at around or below 6000C. The spinel lamellae within Ti-magnetite exsolved at least between 4900 and 5700C.The individual ilmenite grains formed at later stage during high $\mathrm{fO} 2$ condition which replaces the early titanomagnetite. During hydrothermal stage, ilmenite crystallizes in the fracture filling veins. With further lowering of temperature magnetite is altered to martite by weathering or low temperature hydrothermal process. The sulfide grains well within magnetite are formed as liquid immiscibility product at the early magmatic stage. Some sulphides like chalcocite, covellite might have formed during much later supergene or low temperature hydrothermal processes.

\section{Genesis of Ore Bodies}

Genesis of the titaniferous magnetite ores is very important to understand their origin and common association with mafic rocks. In the present area the ore bodies mainly occur as lenses, veins, bands, pockets and segregatedbodies of typical magmatic character. Detailed geochemical analyses of minor and trace elements also attest to their igneous origin. Processes responsible for the formation of Ti-V magnetite ore 
bodies in gabbroic rocks include liquid immiscibility (Lister [30]; Reynolds [31]; Zhou [32]), fractional crystallization of slowly cooled magma with dominant plagioclase buoyancy effect (Charlier [33]), residual liquid injection (Das and Mukherjee [34]), change in oxygen content (Klemm [35]) and change in pressure (Cawthorn and Ashwal [36]). Bateman [37] suggested the concept of late gravitative liquid enrichment for the formation of magnetite ore bodies associated with gabbroic rocks. Crystallization of Ti-V magnetite ores from basaltic magma depends on ferrous/ferric ratio of the liquid, which is a function of $\mathrm{fO} 2$, temperature and water content of the magma (Reynolds [38]) Extensive crystallization of olivine, pyroxene and plagioclase in tholeiitic magma causes increase in $\mathrm{Fe} 2 \mathrm{O} 3 / \mathrm{FeO}$ ratio and overall Fe content in the residual magma respectively. Such fractional crystallization of tholeiitic magma along an iron enrichment trend leads to saturation of $\mathrm{Fe}$ in the residual liquid leading to crystallization of magnetite at the end stage of crystallization process (Irvine [39]). According to Mohanty and Paul [20], the interstitial nature of the ore minerals within the gabbroic rocks is explained by filter pressing mechanism and later on the concentrated residual liquid is injected into the host rocks (gabbroic rock) to form the discordant ore bodies. Microscopic study shows presence of amphibole (ferro-tremolite-hornblende)/biotite at the contact of the iron oxide ores and pyroxene/plagioclase feldspar. Such texture indicates the high water content of magma at this stage of crystallization (due to the presence of amphibole and biotite). This high water content later leads to increase in $\mathrm{fO} 2$ (by dissociation of water molecules), which facilitates extensive crystallization of titanomagnetite ores at the late stage (Das [21]). According to Mohanty and Paul [20], the oxidation of the ore assemblages is due to late stage cooling/or weathering rather than due to dissociation of water.

\section{Conclusion}

In the East Indian Shield, the titaniferous magnetite ore deposits of Archean age are mainly located in the Kumhardubi-Betjharan of Mayurbhanj district, Odisha; Dublabera of West Singhbhum, district, Jharkhand and Baula-Nuasahi of Kendujhar district, Odisha. In these areas the ore bodies occur as lenses, veins, bands and patches within gabbroic intrusives. The magnetite ores along with gabbro-anorthosite intrusives are considered to be syn-to late-kinematic with respect to the IOG greenstone belt of EIS Worldwide occurrences of such associations of Archean mafic intrusions with Archean greenstone belts also attest to their synchronous origin with Iron ore greenstone belt. Archean age of these magnetite ore bodies is also reported in Auge [6]. Detailed geochemical study shows that the ore composition falls on ulvospinel-magnetite join which follows the oxidation trend towards ilmenite-hematite join in $\mathrm{FeO}$ Fe2O3-TiO2 system. Different textures like crystallographic intergrowth, oxidation-exsolution at different temperatures and martitization support the oxidation trend and lowering of temperature. The high $\mathrm{Co} / \mathrm{Ni}$ ratio and the higher concentrations of $\mathrm{Cr}$ and Tiin the magnetite ores clearly indicate their igneous origin. The analytical values of individual minerals reveal significant concentration of $\mathrm{V}$ in ilmenite along with magnetite. Besides $\mathrm{Ti}$ and $\mathrm{V}$, the magnetite ores also have characteristic association of some other valuable metals like gold, platinum and zirconium. The origin of the massive ore bodies is ascribed to late magmatic crystallization from tholeiitic magma followed by $\mathrm{Fe}-\mathrm{Ti}$ enriched residual liquid injection within the host rocks. The coarse grain and interlocking texture shown by magnetite is achieved later by post cumulus sintering or annealing process at elevated sub-solidus temperature.

\section{Acknowledgements}

The authors would like to thank Sri Supriyo Biswas, Senior Research Fellow and Sri Rupam Ghosh, Junior Research Fellow, Dept. of Geological Sciences, Jadavpur University for their constructive suggestion and heartfelt cooperation. Research grant [F.No.11 (6)/2007-TW] by the Ministry of Steel, Govt. of India to TKB is also gratefully acknowledged.

\section{References}

[1] Chakraborty, K.L. and Mallik, A.K., 1968: Mineralogy and temperature of formation of titaniferous magnetite ores associated with gabbro in the Moulabhanjaparbat area, Dhenkanal district, Orissa. Bull. Geol.Soc. India, 5, 134-137.

[2] Vasudev, V.N. and Srinivasan, R., 1979: Vanadium-bearing titaniferous magnetite deposits of Karnataka, India. Jour. Geol. Soc. India, 20, 170-178.

[3] Vidyashankar, H.V. and Govindaiah, S., 2009: Ore petrology of the V-Ti magnetite (lodestone) layers of the Kurihundi area of Sargur Schist Belt, Dharwar Craton. Jour. Geol. Soc. India, $74,58-68$.

[4] Subba Rao, D.V., Basu, E.V.S.S.K., Balaram, V. and Vidyasagar, G., 2014: Geochemical Study of the UltramaficMafic Plutonic and Volcanic Suites of the Nuggihalli Schist Belt, Western Dharwar Craton. Jour. Geol. Soc. India, Spec. Publ. no. 2, 107-126.

[5] Saha, A.K.. 1988: Some aspects of the crustal growth of the Singhbhum-Orissa Iron Ore craton, eastern India. Ind. J. Geol. 60(4), 270-278.

[6] Auge, T., Cocherie, A., Genna, A., Armstrong, R., Guerrot, C., Mukherjee, M.M. and Patra, R.N., 2003: Age of the Baula PGE mineralization (Orissa India) and its implications concerning the Singhbhum Archean Nucleus. Precambrian Res., 121, 85-101.

[7] Iyengar, S.V.P. and Alwar, M.A., 1965: The Dhanjori eugeosyncline and its bearing on the stratigraphy of the Singhbhum, Keonjhar and Mayurbhanj districts. D.N. Wadia Commen. Vol., Geol. Min. Met Soc. India. 138-162.

[8] Shackleton, R.M., 1995: Tectonic evolution of greenstone belts. From Coward, M.P. and Ries, A.C. (eds), 1995, Early Precambrian Processes, Geological Society, Special Publication No. 95, 53-65. 
[9] Wilson, J.F., Nesbitt, R.W., and Fanning, C.M., 1995: Zircon geochronology of Archean felsic sequences in the Zimbabwe craton: a revision of greenstone stratigraphy and a model for crustal growth. From Coward, M.P. and Ries, A.C. (eds), Early Precambrian Processes, Geological Society, Special Publication No. 95, 109-126.

[10] Trendall, A.F., 1995: Paradigms for the Pilbara. From Coward, M.P. and Ries, A.C. (eds), Early Precambrian Processes, Geological Society, Special Publication No. 95, 127-142.

[11] Choukroune, P., Bouhallie, H. and Arndt, N.T., 1995: Soft lithosphere during periods of Archean crustal growth or crustal reworking. From Coward, M.P. and Ries, A.C. (eds), Early Precambrian Processes, Geological Society, Special Publication No. 95, 67-86.

[12] Myers, J.S., 1995: The generation and assembly of an Archean Supercontinent: evidence from the Yilgarncraton, Western Australia. From Coward, M.P. and Ries, A.C. (eds), Early Precambrian Processes, Geological Society, Special Publication No. 95, 143-154.

[13] Windley, B.F., 1977: The evolving Continents. Typeset in Linotron Times and printed by J. W. Arrowsmith Ltd. Bristol.

[14] Baidya, T.K., 2015: Archean Metallogeny and crustal evolution in the East Indian Shield. Jour. Earth Sciences, Special issue (accepted; to be published by July, 2015).

[15] Dunn, J.A. and Dey, A.K, 1937: Vanadium bearing titaniferous magnetite iron ores in Singhbhum and Mayurbhanj, India. Trans. Min. Geol. Inst. India, XI, pt.3, 117-194.

[16] Roy, S., 1956: Origin of the vanadium bearing titaniferous magnetite ores of Mayurbhanj, India. Proc. Nat. Inst. Sci. India, 22, 285-292.

[17] Chakraborty, K.L., Roy, J. and Majumder, T., 1988: Structures and textures of vanadium bearing titaniferous magnetite ores and their interpretation. Jour. Geol. Soc. India, 31, 305-313.

[18] Das, S.K., 1995: Petrology, mineralogy and geochemistry of gabbro-anorthosite suite of rocks and origin of the associated magnetite deposits of Amdabera-Hatichhar area, Mayurbhanj district, Orissa, India. Unpublished Ph.D. Thesis, Utkal University.

[19] Haggerty, S.E., 1976: Opaque mineral oxides in terrestrial igneous rocks. In 'Review in Mineralogy - Oxide Minerals'. Mineralogical Society of America. ed. Douglas Rumble, 3, 101-299.

[20] Mohanty, J.K. and Paul, A.K., 2008: Fe-Ti-oxide Ore of the Mesoarchean Nuasahi Ultramafic-Mafic Complex, Orissa and its Utilization Potential. Jour. Geol. Soc. India, 72, 623-633.

[21] Das, S.K., 2014: Mineralogy and Ore Petrography of Vanadiferous Titaniferous Magnetite Ores of Mayurbhanj Basic Igneous Complex, Odisha. Jour. Geol. Soc. India Spec. Publ., 2, 127-137.

[22] Chevallier, R., Bolfa, J. and Mathieu, S., 1955: Titanomagnetites et ilmenites ferromagnetiques. Bull. Soc. Franc. Min. Crist., 78, 307-346.

[23] Frietsch, R., 1970: Sveriges Geol. Unders Arsbok, 64.
[24] Shaw, G.M., 1964: Interpretation geochimique des elements en Frances dans Les rockes Cristallina, Mason, Paris.

[25] Middlemost, E.A.K., 1985: Magmas and magmatic rocks. Longman, London.

[26] Cox, K.G., Bell, J.D. and Pankhurst, R.J., 1979: The interpretations of igneous rocks. George, Allen and Unwin, London.

[27] Miyashiro, A., 1974: Volcanic rock series in island arcs and active continental margins. Am. J. Sci. 274,321-55.

[28] Irvine, T.N. and Baragar, W.R.A., 1971: A guide to the chemical classification of the common volcanic rocks. Can. Earth Sci., 8, 523-548.

[29] Shervais, J.W., 1982: Ti-V plots and the petrogenesis of modern and ophiolitic lavas. Earth Planet Sci. Lett., 59, 101113.

[30] Lister, G.F., 1966: the composition and origin of selected irontitanium deposits. Econ. Geol., 61, 275-310.

[31] Reynolds, I.M., 1985b: The nature and origin of titaniferous magnetite-rich layers in the upper zone of the Bushveld complex; a review and synthesis. Econ. Geol., 80, 1089-1108.

[32] Zhou, M., Robinson, P.T., lesher, C.M., Keays, R.R., Zhang, C.J. and Malpas, J., 2005: Geochemisttry, Petrogenesis and Metallogenesis of the Panzhiua gabbroic layered intrusion and associated Fe-Ti-V oxide deposits, Sichuan province, SW China. Jour. Petrol., 46, 2253-2280.

[33] Charlier, B., Duchesne, J.C. and Auwera, J.V., 2006: Magma chamber processes in the Tellnes ilmenite deposit (Rogaland Anorthosite Province, SW Norway) and the formation of FeTi ores in massif-type anorthosites. Chemical Geology, 234, 264-290.

[34] Das, S.K. and Mukherjee, S., 2001: Mineralogy geochemistry of V-Ti magnetite deposits of Mayurbhanj basic igneous complex, Orissa, Indian Mineralogist, 35, 134-150.

[35] Klemn, D.D., Henckel, J., Dehm, R., and Von Gruenewaldt, G., 1985: The geochemistry of titanomagnetite in magnetite layers and their host rocks of the Eastern Bushveld Complex. Econ. Geol., 80, 1075-1088.

[36] Cawthorn, R.G. and Ashwal, L.D., 2009: Origin of anorthosite and magnetite layers in the Bushveld complex: constrained by major element compositions of plagioclase. Jour. Petrol., 50, 1607-1637.

[37] Bateman, A.M., 1951: The formation of late magmatic oxide ores. Econ. Geol., 46, 404-426.

[38] Reynolds, I.M., 1985a: Contrasted mineralogy and textural relationships in the uppermost titaniferous magnetite layers of the Bushveld Complex in the Bierkraal area, north of Rustenburg. Econ. Geol., 80, 1089-1108.

[39] Irvine, T.N., 1975: Crystallization sequences in Muskox intrusion and other layered intrusions. 2. Origin of chromitite layers and similar deposits of other magmatic ores. Geochim.et Cosmochim. Acta, 39, 991-1020. 